DOE/RL-97-54

Revision 0

1997 Evaluation of

Tritium Removal and

Mitigation Technologies

for Hanford Site

Wastewaters

United States

Department of Energy

Richland, Washington

Approved for Public Release 


\section{Evaluation of Tritium Removal and Mitigation Technologies for Hanford Site Wastewaters}

D. W. Jeppson

R. K. Biyani

J. B. Duncan

SGN Eurisys Services Corporation (SESC)

D. L. Flyckt

P. C. Mohondro

Waste Management Federal Services of Hanford, Inc.

\section{G. L. Sinton}

U.S. Department of Energy, Richland Field Office

Date Published

July 1997

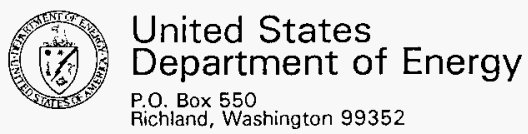


LEGAL DISCLAIMER

This report was prepared as an account of work sponsored by an agency of the United States Government. Neither the United States Government nor any agency thereof, nor any of their employees, nor any of their contractors, subcontractors or their employees, makes any warranty, express or implied, or assumes any legal liability or responsibility for the accuracy, completeness, or any third party's use or the results of such use of any information, apparatus, product, or process disclosed, or represents that its use would not infringe privately owned rights. Reference herein to any specific commercial product, process, or service by trade name, trademark, manufacturer, or otherwise, does not necessarily constitute or imply its endorsement, recommendation, or favoring by the United States Government or any agency thereof or its contractors or subcontractors. The views and opinions of authors expressed herein do not necessarily state or reflect those of the United States Government or any agency thereof.

This report has been reproduced from the best available copy. Available in paper copy and microfiche.

Available to the U.S. Department of Energy and its contractors from

Office of Scientific and Technical Information P.O. Box 62

Oak Ridge, TN 37831

(615) 576-8401

Available to the public from the U.S. Department of Commerce National Technical Information Service

5285 Port Royal Road

Springfield, VA 22161

(703) 487.4650

Printed in the United States of America

DISCLM-1.CHP (1-91) 
DOE/RL-97-54, Rev. 0

1997 EVALUATION OF

TRITIUM REMOVAL AND MITIGATION TECHNOLOGIES

FOR HANFORD SITE WASTEWATERS

\author{
D. W. Jeppson \\ R. K. Biyani \\ J. B. Duncan
}

\begin{abstract}
A biennial assessment of separation technologies and other mitigation techniques to control tritium in liquid effluents and groundwater at the Hanford Site is presented herein. This report was prepared to satisfy the Hanford Federal Facility and Consent Order (Tri-Party Agreement Milestone M-25-05D).
\end{abstract}

The objectives of this assessment are to 1) identify viable processes which can be used to reduce tritium concentrations in current Hanford Site liquid discharges and existing groundwater to below the 40 CFR 141.16 drinking water tritium maximum contaminant level (MCL) concentration of 20,000 pCi/L and/or to DOE Order 5400.5 as low as reasonably achievable (ALARA) policy and 2) identify control methods to prevent the flow of tritiated water (HTO) (at tritium concentrations greater than the MCL) to the Columbia River. Current tritium releases are in compliance with applicable United States Environmental Protection Agency, Washington State Department of Ecology, and United States Department of Energy requirements under the agreed to Hanford Federal Facility and Consent Order.

Technologies and other mitigation techniques for control of tritium in liquid effluents and groundwater at the Hanford Site are grouped into three categories for evaluation in this report. The first group consists of commercial hydrogen isotope separation processes that would require additional development work to adapt to the duty of reducing light water (protium oxide with about $150 \mathrm{ppm}$ deuterium oxide) tritium concentrations to the MCL. The second group consists of technical models, laboratory studies, or pilot plant processes to address the reduction of tritium concentration in liquid effluents or groundwater to the MCL concentration. The third group consists of other mitigation techniques which may be used to isolate or remove tritium.

The first group includes the following large-scale commercial hydrogen isotope separations processes:

\footnotetext{
- Water electrolysis

- Water distillation

- Hydrogen distillation

- Combined electrolysis catalatic exchange

- Girdler-sulfidey
} 
These processes have been developed to a commercial scale for separating deuterium from light water, concentrating deuterium to high purity, and/or removing tritium from heavy water (deuterium oxide) and concentrating tritium to a high purity. None of these processes are used on a large commercial scale for separating low concentrations of tritium from light water to meet the MCL concentration. All of these processes require large amounts of energy to operate and would require additional development work to determine if they may be practical to perform the required duty for separation of tritium from light water to MCL concentrations on a large scale. Computer codes have been developed for modeling process effectiveness and cost estimates of capital equipment and processing costs for several of these processes. These codes could be used for defining technically feasible processes or combination of processes for which cost estimates could be made to clean HTO to the MCL concentration.

The second group includes processes postulated, laboratory tested, or pilot plant tested for tritium removal from light water to the MCL concentration or less. These processes include 1) liquid phase catalatic exchange with hot elly or solid oxide electrolyte, 2) polyphosphazine membrane, 3) laser isotope separation, 4) sulfur resin exchange, and 5) metal hydride based isotope exchange.

The third group includes mitigation techniques for tritium isolation, decay, and/or removal. These techniques include routing of future effluents containing tritium to a low percolation rate aquifer, establishing tritium barriers of aquifers by targeted freezing, concrete, or metal and air sparging to remove tritium from groundwater.

Tritium inventories at the Hanford Site include waste stored in the high-level waste tanks: 100-K East, 100-K West, and 100-N Areas reactor fuels storage basin water; solid-waste disposal sites; and numerous groundwater deposits and flows. Tritium production since 1944 at the Hanford Site, excluding product tritium shipped offsite, amounts to a 1997 decayed (tritium half 7 ife of 12.3 years) value of $2.0 \times 10^{5} \mathrm{Ci}(2 \mathrm{~g})$ as calculated from a 1993 Robyler spread sheet (Robyler 1997). Estimated tritium inventories of waste tanks, other impoundments, and underground aquifers at the Hanford Site are included in this report.

Although technologies exist to reduce tritium concentrations typical of Hanford Site wastewaters to the MCL concentration, the applications need further demonstration and cost evaluation. One of these technologies was implemented in the 1980 's at Mound Laboratories on a small scale. Additional technologies have since been developed to accomplish the same at laboratory scale. Technologies have been proposed to accomplish this for larger scale application but need further demonstration and cost evaluation. It appears that targeted application could minimize the size requirements to where a wastewater tritium removal technology may be considered. 
TABLE OF CONTENTS

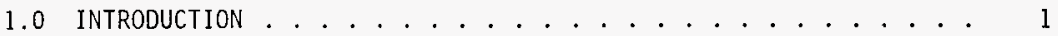

2.0 SEPARATION AND ISOLATION TECHNOLOGIES FOR TRITIUM IN WASTEWATERS 2

2.1 GROUP ONE TECHNOLOGIES FOR SEPARATING TRITIUM FROM HANFORD

WASTEWATER ................... 2

2.1.1 Water Distillation ........... 3

2.1.2 Hydrogen Isotope Distillation (Cryogenic Distillation) 4

2.1.3 Water Electrolysis ........... . 4

2.1.4 Combined Electrolysis Catalatic Exchange (CECE) . . 5

2.1.5 Girdler-Sulfide Process . . . . . . . ... 5

2.2 GROUP TWO TECHNOLOGIES FOR SEPARATING TRITIUM FROM WASTEWATER 7

2.2.1 Liquid Phase Catalytic Exchange with Solid Oxide Electrolyte ............... 7

2.2.2 Liquid Phase Catalytic Exchange with Hot Elly ... 11

2.2.3 Membrane Mediated Separation of Tritiated Water From Wastewater ............. 11

2.2.4 Laser Induced Tritium Separation ......... 15

2.2.5 Tritium Removal from Wastewater Using Sulfur Resin Ion Exchange ............. 19

2.2.6 Tritium Removal from Wastewater Using Metal Hydride Exchange ............. 21 21

2.3 GROUP THREE MITIGATION TECHNIQUES FOR TRITIUM IN GROUNDWATER 23

2.3.1 Permitted Discharge . . . . . . . . . 23

2.3.2 Barrier Formation ............. . . 24

2.3 .3 Air Sparging . . . . . . . . . . . . 24

3.0 TRITIUM AT THE HANFORD SITE . . . . . . . . . . . . . . 24

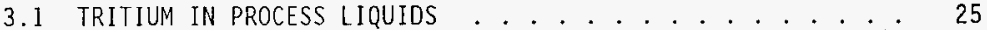

3.2 GROUNDWATER SAMPLING $\ldots \ldots \ldots \ldots$

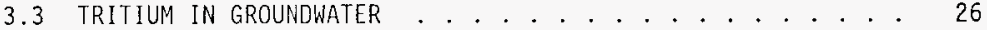

3.3.1 100-Area Tritium Plumes . . . . . . . . . . 29

3.3.2 200-West Area Plumes . . . . . . . . . . . . . . . . 29

3.3.3 200-East Area Plumes . . . . . . . . . . . . . . . . 29

3.3 .4300 Area . . . . . . . . . . . . . . . . 29

3.4 GROUNDWATER MODELING $\ldots \ldots \ldots \ldots$

3.5 OPERATION OF STATE-APPROVED LAND DISPOSAL SITE . . . . . . 31

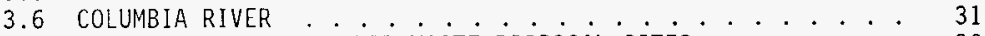

3.7 TRITIUM STORED IN SOLID-WASTE DISPOSAL SITES ...... 32

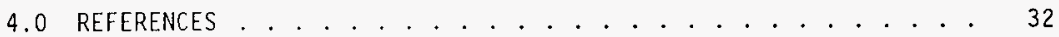


D0E/RL-97-54, Rev. 0

\section{LIST OF TABLES}

1 Single-Stage Theoretical Separation Factors for Hydrogen Isotopes 3

2 Comparison of Estimated Costs and Energy Consumption for Separation

Processes ................... . . . 4

3 Comparison of Group Two Development Processes to Separate Tritium

from Water .................. . . 8

4 Estimated Tritium Inventories in Process Liquids

at the Hanford Site . . . . . . . . . . . . . 26

5 Tritium Concentration and Supernatant Volume in Some Double-Shell Tanks ...................... 27

6 Tritium Concentrations and Approximated Areas of Hanford Site Aquifers at $20,000 \mathrm{pCi} / \mathrm{L}$ or Greater ........... . . 29

\section{LIST OF FIGURES}

1 Girdler-Sulfide Process for Tritium Removal From Wastewater . . 6

2 Dual Temperature Liquid Phase Catalytic Exchange with Solid 0xide Electrolysis.................... . . . 10

3 Dual Temperature Liquid Phase Catalytic Exchange with Hot Elly . 12

4 Tritium Removal from Wastewater Using Polyphosphazine Membrane . 14

5 Laser Isotope Separation of Tritium from Water Vapor . . . . . 16

6 Laser Isotope Separation of Tritium With Trifluoromethane . . . 17

7 Tritium Removal From Wastewater Utilizing Sulfur Resin . . . . . 20

8 Tritium Removal From Hydrogen Gas Using Metal Hydride Isotopic

Separation....................... . . . 22

9 Tritium Movement in Hanford Site Groundwater . . . . . . . . . . 28

10 Tritium concentration Trend in Wel1 299-W22-9. . . . . . . . . 30 


\section{ABBREVIATIONS}

\begin{tabular}{|c|c|}
\hline $\begin{array}{l}\text { AECL } \\
\text { ALARA }\end{array}$ & $\begin{array}{l}\text { Atomic Energy of Canada, Ltd. } \\
\text { as low as reasonably achievable }\end{array}$ \\
\hline BHI & Bechtel Hanford, Inc. \\
\hline $\begin{array}{l}\text { CECE } \\
\text { CFEST } \\
\text { CFR }\end{array}$ & $\begin{array}{l}\text { combined electrolysis catalytic exchange } \\
\text { coupled fluid energy, and soluble transport } \\
\text { Code of Federal Regulations }\end{array}$ \\
\hline DOE & U.S. Department of Energy \\
\hline ETF & Effluent Treatment Facility \\
\hline FRG & Federal Republic of Germany \\
\hline IR & infrared \\
\hline $\begin{array}{l}\text { K } \\
\text { KE } \\
\text { KW }\end{array}$ & $\begin{array}{l}\text { Kieselguhr } \\
105 K \text { East Area } \\
\text { 105K West Area }\end{array}$ \\
\hline LPCE & liquid phase catalytic exchange \\
\hline $\begin{array}{l}M C L \\
M P D\end{array}$ & $\begin{array}{l}\text { maximum contaminant level } \\
\text { multiphoton dissociation }\end{array}$ \\
\hline OHRD & Ontario Hydro Research Division \\
\hline $\begin{array}{l}\text { PFR } \\
\text { PUREX }\end{array}$ & $\begin{array}{l}\text { plug flow reverser } \\
\text { Plutonium Uranium Extraction (Facility) }\end{array}$ \\
\hline $\begin{array}{l}\text { REDOX } \\
\text { RIKEN } \\
\text { RTF }\end{array}$ & $\begin{array}{l}\text { Reduction Oxidation (F-Plant) } \\
\text { Institute of Physical and Chemical Research } \\
\text { Replacement Tritium Facility }\end{array}$ \\
\hline $\begin{array}{l}\text { SALDS } \\
\text { SOE }\end{array}$ & $\begin{array}{l}\text { state-approved land disposal site } \\
\text { solid oxide electrolyte }\end{array}$ \\
\hline TCAP & thermal cycling absorption process \\
\hline VAM3DCG & $\begin{array}{l}\text { Variable Saturated Analysis Model in } \\
3 \text { Dimensions with Preconditioned Conjugate } \\
\text { Gradient Matrix Solvers }\end{array}$ \\
\hline
\end{tabular}




\section{SCIENTIFIC SYMBOLS AND ABBREVIATIONS}

Units of Measure

\begin{tabular}{ll} 
Unit & Definition \\
\hline $\mathrm{L}$ & $\begin{array}{l}\text { liter } \\
\text { meter }\end{array}$ \\
$\mathrm{g}_{\mathrm{k}}$ & gram \\
$\mathrm{C} \mathrm{degree}$ & curie kelvin (absolute temperature) \\
$\mathrm{ppm}$ & parts per million $\left(10^{-6}\right)$ \\
$\mathrm{ppt}$ & parts per trillion $\left(10^{-9}\right)$ \\
ppqd & parts per quaddrillion $\left(10^{-15}\right)$
\end{tabular}

Magnitude Modifies

Symbol Unit

$\begin{array}{ll}\mathrm{mCi} & \text { milli curie } \\ \mu \mathrm{Ci} & \text { micro curie } \\ \mathrm{p} & \text { pico curie }\end{array}$
Amount

$$
\begin{aligned}
& \left(10^{-3}\right. \text { curie) } \\
& \left(10^{-6}\right. \text { curie) } \\
& \left(10^{-12}\right. \text { curie) }
\end{aligned}
$$

Elements and Compounds Symbol

Hydrogen Isotopes

$H\left({ }^{H}\right)$ protium

D $\left({ }_{3}^{2} \mathrm{H}\right)$ deuterium

$\mathrm{T}\left({ }^{3} \mathrm{H}\right)$ tritiun:
Atomic Mass

1
2
3
CO

$\mathrm{D}_{2}$

$D_{2} 0$

DMSO

DTO

$\mathrm{H}_{2}$

$\mathrm{H}_{2} \mathrm{O}$

HD

He

HT

HTO

$\mathrm{Pd}$

$T^{2} / H$

TF

THS cryogenic distillation

deuterium molecule deuterium oxide (heavy water)

dimethyl sulfoxide

tritiated deuterium

tritiated deuterium oxide

hydrogen molecule

water (1ight water-protium oxide)

deuterated hydrogen

deuterated water

helium

tritiated hydrogen

tritiated water

palladium

tritium molecule

tritium to protium ratio

tritium fluoride

tritiated hydrogen sulfide 
DOE/RL-97-54, Rev. 0

\section{RADIOACTIVITY LEVEL CONVERSIONS}

\begin{tabular}{|c|c|c|c|}
\hline $\mathrm{pCi} / \mathrm{L}$ & $\mu \mathrm{Ci} / \mathrm{L}$ & $\mathrm{Ci} / \mathrm{L}$ & $\mu \mathrm{Ci} / \mathrm{mL}$ \\
\hline $10^{4}$ & 0.01 & $10^{-8}$ & 0.00001 \\
\hline $10^{5}$ & 0.1 & $10^{-7}$ & 0.0001 \\
\hline $10^{6}$ & 1 & $10^{-6}$ & 0.001 \\
\hline $10^{7}$ & 10 & $10^{-5}$ & 0.01 \\
\hline $10^{8}$ & 100 & $10^{-4}$ & 0.1 \\
\hline $10^{9}$ & 1,000 & $10^{-3}$ & 1 \\
\hline $10^{10}$ & 10,000 & $10^{-2}$ & 10 \\
\hline $10^{11}$ & 100,000 & $10^{-1}$ & 100 \\
\hline $10^{12}$ & $1,000,000$ & 1 & 1,000 \\
\hline
\end{tabular}


DOE/RL-97-54, Rev. 0

\section{EVALUATION OF \\ TRITIUM REMOVAL AND MITIGATION TECHNOLOGIES FOR HANFORD SITE WASTEWATERS}

\subsection{INTRODUCTION}

This report contains results of a biennial assessment of tritium separation technology and tritium mitigation techniques for control of tritium-bearing wastewaters at the Hanford Site. Tritium in wastewaters at Hanford have resulted from plutonium production, fuel reprocessing, and waste handling operations since 1944. This assessment was conducted in response to the Hanford Federal Facility Agreement and Consent Order (Tri-Party Agreement Milestone M-25-05D, Ecology et. a1.), which states:

"Submit to EPA and Ecology an evaluation of development status of tritium treatment technology that would be pertinent to the cleanup and management of tritiated wastewater (e.g., the 242-A Evaporator process condensate 1 iquid effluent) and tritium-contaminated groundwater at the Hanford Site." This milestone has a completion date of August 31, 1997.

The information in this report presents the tritium separations technologies and tritium mitigation techniques currently available. An estimate of tritium inventories in the wastewaters at Hanford is also given to provide a general understanding of the present situation. Additional background material is available in previous assessments and related reports (U.S. Department of Energy [DOE] 1995, Hartman 1997, Waters 1988, Dirks 1994, McConachie 1996, and Fulbright 1996).

Conversion of tritium at low wastewater concentrations to nonradioactive elements by fission or fusion processes is very unlikely because of costs and associated activation products of processing materials. This approach was not considered, therefore, the main effort for tritium removal and mitigation at Hanford discussed in this report focuses on separation and isolation.

A substantial worldwide effort is being expended upon technologies to separate and recover tritium because of its market value and its potential radiation exposure to the general public and operations personnel associated with heavy-water reactors and deuterium tritium (DT) fusion reactors. Human exposure concerns of tritium are related more to ingestion rather than external exposure. Major uses for tritium include:

- Fuel in experimental fusion reactors

- Luminescent material for exit signs and clock displays

- Research and medical tracer

Technology development for removal of tritium from liquid effluents to satisfy environmental concerns is proceeding at a more modest level. To some extent, tritium production and tritium removal technologies are complementary and can be used together to treat wastewaters. However, technology to reduce Hanford Site liquid effluents to concentrations satisfying the tritium maximum containment level (MCL) requires an extensive additional effort beyond the product preparation effort for marketing tritium product. An approach for the Hanford Site related to separation technology is to detritiate large volumes 
of wastewater such that the bulk of the water could be released to the ground at less than the MCL tritium concentration. This process could result in small volumes of concentrated tritiated waste which could be handled at reasonable costs.

\subsection{SEPARATION AND ISOLATION TECHNOLOGIES FOR TRITIUM IN WASTEWATERS}

Separation and isolation technologies to control tritium concentrations in the Hanford Site liquid effluent and groundwaters to meet the Code of Federal Regulations (CFR), 40 CFR 141.14 drinking water MCL of 20,000 pCi/L $(\sim 2 \mathrm{ppQD})$ and/or DOE order 5400.5 as 10 w as reasonably achievable (ALARA) are identified and evaluated. Tritium recovery markets desire tritium at high purities or concentrations of about $100 \mathrm{Ci} / \mathrm{L}(10 \mathrm{ppm})$ or greater when removing tritium from Hanford Site wastewater. This great difference (factor of about $5 \times 10^{9}$ ) is not all unrelated. To clean up wastewater to MCL concentrations and to minimize recovered tritium volume, technologies may be desirable to concentrate tritium to near the market values in a very small fraction of the wastewater. The current market value for the estimated remaining process tritium at Hanford, if recovered and in a pure state, is less than $\$ 50,000$ at the current market price of approximately $\$ 15$ per curie. This market value of remaining Hanford tritium is insignificant when compared to the cost of recovery from process streams. Potential public exposure and land reclamation are the two main driving forces for meeting these concentration limits.

Relevant hydrogen isotope separation technologies are grouped into three categories for the purpose of evaluation in this report. The first group consists of commercial hydrogen isotope separation technologies which would require additional development work to adapt to the duty of reducing light water tritium concentrations to the $\mathrm{MCL}$. The second group includes processes modeled, laboratory tested, or pilot plant tested for tritium removal from light water to MCL concentrations or less. The third group includes mitigation techniques for tritium isolation, decay and/or removal. Evaluation of tritium isolation techniques are also included for potential applications to existing groundwater deposits at Hanford.

\section{I GROUP ONE TECHNOLOGIES FOR SEPARATING TRITIUM FROM HANFORD WASTEWATER}

There are no commercial processes operating today to reduce tritium in Hanford wastewaters at concentrations of interest (near $10 \mu \mathrm{Ci} / \mathrm{L}, 0.5 \mathrm{ppT}$ ) to less than the MCL from large stream flows of wastewater. There are many commercial processes for separating deuterium oxide (deuterium at $150 \mathrm{ppm}$ ) from protium oxide and separating tritium from deuterium and for concentrating deuterium or tritium to obtain a product (greater than 900,000 ppm) of marketable value and for reducing tritium concentrations (to about $1 \mathrm{Ci} / \mathrm{L}$, $50 \mathrm{ppm}$ ) in heavy water to minimize worker exposure. These processes include water distillation, hydrogen isotope distillation, water electrolysis, combined electrolysis catalytic exchange (CECE), and a girdler-sulfide process. These processes by themselves are judged to be not commercially developed and/or too costly to be used for wastewater treatment to remove tritium to less than MCL concentrations on a large scale.

Total separation factors (concentration of enriched stream/concentration of depleted stream for total process) required for the Hanford Site streams of interest to reach the MCL concentration and produce an enriched-tritium product stream are very large. The total separation factors desired for 
Hanford are much greater than those in commercial application for producing concentrated product from relatively rich starting streams (tritium concentrations near $1 \mathrm{C} i / L)$ by the above processes. The theoretical stage separation factors (concentration of enriched stream/concentration of depleted stream for one equilibrium stage) for separating tritium from protium are greater than those for separating deuterium from tritium or protium. These greater separation factors for tritium separation from protium make it easer to separate than for deuterium separation from protium. However, natural water has a greater content of deuterium (about $150 \mathrm{ppm}$ ) than the tritium content of interest, $10 \mu \mathrm{Ci} / \mathrm{L}(1 \mathrm{ppT})$, and can add to the removal burden. $A$ comparison of separation factors is listed in Table 1.

Table 1. Single-Stage Theoretical Separation Factors for Hydrogen Isotopes.

\begin{tabular}{|c|c|c|c|c|}
\hline \multirow{2}{*}{ Process } & \multirow{2}{*}{ Temperature ${ }^{\circ} \mathrm{K}$} & \multicolumn{3}{|c|}{ Ratio } \\
\hline & & $H / D$ & $\mathrm{D} / \mathrm{T}$ & $\mathrm{H} / \mathrm{T}$ \\
\hline Water distillation & 333 & 1.05 & 1.0125 & 1.056 \\
\hline $\begin{array}{l}\text { Hydrogen } \\
\text { distillation }\end{array}$ & $21-24$ & 1.56 & 1.2 & 1.82 \\
\hline Electrolysis & 353 & 5.6 & 2. & 10 \\
\hline $\begin{array}{l}\text { Catalatic exchange } \\
\text { VPCE } \\
\text { LPCE }\end{array}$ & $\begin{array}{l}473 \\
298 \\
\end{array}$ & & $\begin{array}{r}1.22 \\
1.67 \\
\end{array}$ & $\begin{array}{l}2.13 \\
7.14 \\
\end{array}$ \\
\hline Girdler-sulfide & $\begin{array}{l}223 \\
293 \\
403 \\
\end{array}$ & $\begin{array}{l}6.60^{\star} \\
2.18^{\star} \\
1.83^{\star}\end{array}$ & $\begin{array}{l}--- \\
--- \\
--- \\
\end{array}$ & $\begin{array}{l}9.9^{\star} \\
3.3^{\star} \\
2.7^{\star}\end{array}$ \\
\hline \multicolumn{5}{|c|}{$\begin{array}{l}\text { chemical reaction equilibrium constants (Rae 1978) } \\
\text { hydrogen to deuterium }(H / D) \\
\text { deuterium to hydrogen }(\mathrm{D} / \mathrm{T}) \\
\text { hydrogen to tritium }(H / T)\end{array}$} \\
\hline
\end{tabular}

\subsubsection{Water Distillation}

The use of water distillation to treat tritiated wastewaters at Hanford is technically feasible. The columns would be operated at about 0.2 atmosphere pressure and $333^{\circ} \mathrm{K}$. Separation factors for hydrogen to tritium water distillation are about 1.056 for these conditions except that a loss in efficiency is encountered at the extremely low tritium concentrations of interest. This water distillation process utilizes counter current flow of steam and liquid phases in the rectifying column, desired phase reversal by condensation at the top and revaporization at the bottom of the column. There is no danger of a hydrogen fire or explosion in this process but it does require a considerable amount of low-grade energy for operation.

Ontario Hydro personnel estimated that 100 distillation units costing $\$ 100 \mathrm{M}$ each (NeTson et. a). 1994) would be required to effect the required separations as shown in Table 2. In addition, energy requirements for evaporation and condensation are large. The high capital and operating costs make this technology impractical even though it is relatively safe. 
Table 2. Comparison of Estimated Costs and Energy Consumption for Separation Processes.

\begin{tabular}{|l|c|c|c|c|}
\hline \multicolumn{1}{|c|}{ Process } & $\begin{array}{c}\text { Feed Flow } \\
\text { Rate } \\
(1 / \mathrm{min})\end{array}$ & $\begin{array}{c}\text { Capital } \\
\text { Equipment Costs } \\
(\$ M)\end{array}$ & $\begin{array}{c}\text { 0perating } \\
\text { Costs } \\
(\$ M / \text { yr })\end{array}$ & $\begin{array}{c}\text { Safety } \\
\text { Concerns }\end{array}$ \\
\hline $\begin{array}{l}\text { Water } \\
\text { distillation }\end{array}$ & $\sim 100$ & 10,000 & -- & low \\
\hline $\begin{array}{l}\text { Hydrogen } \\
\text { distillation }\end{array}$ & 8 & 20 & 12 & high \\
\hline Electrolysis & 8 & 150 & 34 & high \\
\hline $\begin{array}{l}\text { Combined } \\
\text { electrolysis } \\
\text { catalytic } \\
\text { exchangec }\end{array}$ & 95 & 340 & 200 & Moderate \\
\hline $\begin{array}{l}\text { Girdler-sulfide } \\
\text { a (Nelson 1994) } \\
\text { b (Ellis 1982) } \\
\text { c (Fulbright 1996) }\end{array}$ & 95 & 6.1 & 2.5 & high \\
\hline
\end{tabular}

\subsubsection{Hydrogen Isotope Distillation (Cryogenic Distillation)}

Hydrogen cryogenic distillation (CD) requires the conversion of water to hydrogen (conventionaliy by electrolysis) and then a number of low temperature $\left(20\right.$ to $\left.30^{\circ} \mathrm{K}\right)$ separation stages cooled by liquid helium. Tritium single-stage separation factors for removal from protium by $C D$ are about 1.80 . The evaporated gas at each stage is condensed for the next stage. Energy consumption costs for the required tritium separation of interest are too great to be a viable process for the subject application as indicated in Table 2. Safety concerns when working with hydrogen are an integral part of this process.

\subsubsection{Water Electrolysis}

Water electrolysis is a well developed technology. Tritium is concentrated in the electrolyte and depleted in the hydrogen gas evolved. A tritium single-stage separation factor of about 10 is typical for dilute tritiated light water. A number of electrolysis stages would be required to make the desired tritium separation from $10 \mu \mathrm{Ci} / \mathrm{L}$ to less than $0.02 \mu \mathrm{Ci} / \mathrm{L}$. Additional stages would also be needed to further concentrate the enriched tritium to a manageable volume (to a tritium concentration of about $10 \mathrm{Ci} / \mathrm{L}$ ). A hydrogen recombination step would be required between each electrolysis step to convert the gases back to liquid water for the next electrolysis stage. Recycle of many streams would be required to effect a complete separation. The electrolysis process for this application has very high energy consumption costs and safety concerns when working with hydrogen gas on a large scale. The estimated capital equipment and energy costs indicated in Table 2 for a feed rate of about $8 \mathrm{~L} / \mathrm{min}$ show that this method would be too costly. A series of research projects are being carried out with the aim of reducing these energy requirements (Vasaru 1993). 


\subsubsection{Combined Electrolysis Catalatic Exchange (CECE)}

Combinations of some of these processes appear to be technically capable of separating tritium from light water to meet the $\mathrm{MCL}$ concentrations. One of the more attractive processes is a CECE (Ellis 1982) small-scale demonstrated process coupled with an expanded column or a supplemental system to further concentrate the enriched tritium stream. This CECE process consists of an electrolysis cell, a liquid-phase catalytic exchange column, and a recombiner. Hydrophobic catalysts, developed by Atomic Energy of Canada, Ltd. (AECL), has made this technology effective. The process has been demonstrated (Ellis 1982) on a pilot plant scale to process light water with a tritium concentration of $53 \mu \mathrm{C} / \mathrm{L}$ resulting in a water discharge of $0.02 \mu \mathrm{Ci} / \mathrm{L}$ at about $97 \%$ of the feed volume and an enriched stream of $2.0 \mathrm{mC} / \mathrm{L}$ at a $\mathrm{liquid}$ volume of about $3 \%$ of the feed volume.

Capital equipment costs for a portable unit designed to process about $8 \mathrm{~L} / \mathrm{min}$ of feed was estimated to be about $\$ 50 \mathrm{M}$ (adjusted to 1997 dollars). The majority of this capital equipment cost was for the electrolytic cells. Energy requirements for operating the electrolytic cells in this process was estimated to be $5.8 \mathrm{MW}$ on a continuous processing basis. A more recent analysis (Fulbright 1996) gives an estimate of $\$ 340 \mathrm{M}$ capital equipment cost with about $\$ 200 \mathrm{M}$ annual operating costs for processing $95 \mathrm{~L} / \mathrm{min}$ of feed. An expanded column or supplemental process could be used to provide further tritium concentration of the tritium-enriched stream to produce a manageable volume. The capital equipment cost could be distributed over several tritium cleanup sites by utilizing the portable unit concept. The energy costs for operation are quite high.

\subsubsection{Girdler-Sulfide Process}

The girdler-sulfide process has been used since the early 1940 s to separate deuterium from natural water to produce a concentrated deuterium product. This process involves the exchange of deuterium between liquid water and hydrogen sulfide gas according to the equilibrium reaction:

$$
\mathrm{HDS}(\mathrm{g})+\mathrm{H}_{2} \mathrm{O}(1) \leftrightarrows \mathrm{HOO}(1)+\mathrm{H}_{2} \mathrm{~S}(\mathrm{~g})
$$

It is anticipated that the tritium equilibrium exchange between hydrogen sulfide $\left(\mathrm{H}_{2} \mathrm{~S}\right)$ gas and liquid water could be used to separate tritium from tritiated water (HTO) by the similar reaction:

$$
\operatorname{THS}(\mathrm{g})+\mathrm{H}_{2} \mathrm{O}(1) \leftrightarrows \mathrm{HTO}(1)+\mathrm{H}_{2} \mathrm{~S}(\mathrm{~g})
$$

This reaction occurs rapidly without a catalyst. This process was evaluated (Fulbright 1996) to be a more economical process for tritium removal from water-containing tritium at concentrations around $25 \mu \mathrm{Ci} / \mathrm{L}$. This process is expected to produce a releasable water flow of tritium with less than $20,000 \mathrm{pCi} / \mathrm{L}$. Variation of the equilibrium constant with respect to temperature is used as the basis for the separation process to produce an enriched-HTO stream and a tritium-depleted water stream. This process consists of two tower sections with an electrolytic celi as shown in Figure 1. The two tower sections operate at different temperatures. The separation factor is lower in the hot section than in the cold section. Tritium from 1 iquid water reacts with the contacting $\mathrm{H}_{2} \mathrm{~S}$ gas in the hot section to form. tritiated hydrogen sulfide (THS) gas for refluxing in the cold tower. The concentrated tritium is removed from the bottom of the cold tower (top of the 
DOE/RL-97-54, Rev. 0

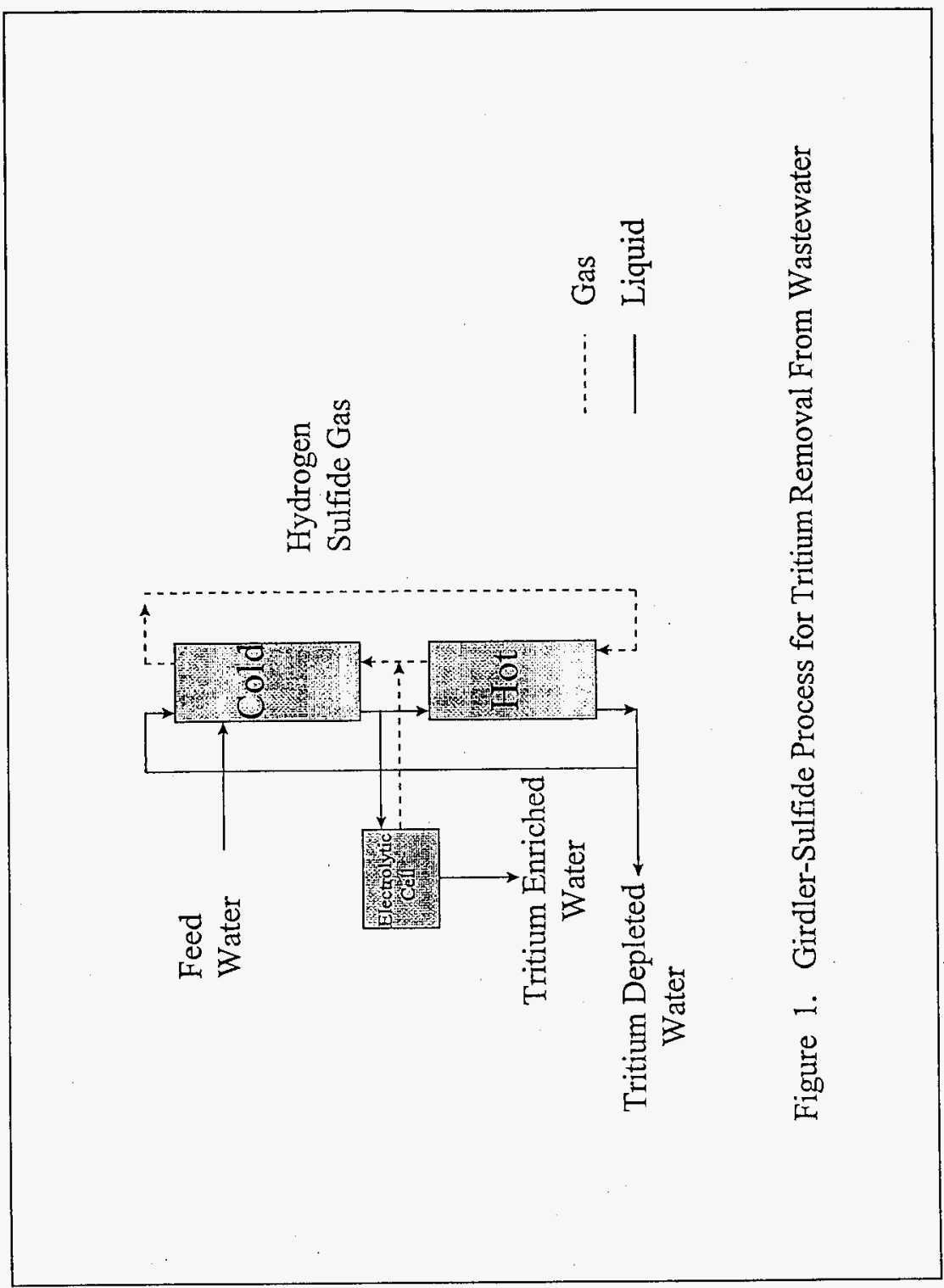


hot tower) and further concentrated by electrolysis. This is a very small stream that is removed for electrolysis. The THS gas in the cold section reacts with water to form HTO and hydrogen sulfide gas which exits the top of the cold column. The water and the gas flow counter-currently through each tower with the liquid water flowing down and the gases flowing upward.

Costs were estimated to be $\$ 6.1 \mathrm{M}$ for capital equipment and $\$ 2.5 \mathrm{M} / \mathrm{yr}$ for operation at $95 \mathrm{~L} / \mathrm{min}$ of feed with a tritium concentration of $25 \mu \mathrm{Ci} / \mathrm{L}$. This process would utilize large distillation towers and operate at about 20 atmospheres pressure. There is corrosion and flammability concerns with using $\mathrm{H}_{2} \mathrm{~S}$ and toxicity concerns with tritiated gases at 20 atmospheres pressure. The hydrogen sulfide content of tritium-depleted liquid effluent need to be controlled within discharge limits. This process has been used for producing tritium and deuterium products but has not been used for removing tritium to the MCL concentration. Further testing and demonstration would be needed prior to implementation of this process.

For the Hanford Site application, a smaller size girdler-sulfide unit may be adequate if it is technically demonstrated to be effective. For example, when processing 105-K East (KE) Area basin water for tritium removal a feed rate of $50 \mathrm{~L} / \mathrm{min}$ could be used to process the basin water in about 63 days of continuous operation. This process would not be expected to process basin water directly, but perhaps after processing the basin water through the Effluent Treatment Facility (ETF) to remove other contaminants first, the resulting condensates could be processed by this smaller-sized girdler-sulfide unit. There would be other targeted applications (wastes needing tritium removal) for which liquids may be processed sequentially through ETF and then through this tritium removal unit to control tritium releases below the MCL concentration.

\subsection{GROUP TWO TECHNOLOGIES FOR SEPARATING TRITIUM FROM WASTEWATER}

Five candidate technologies in development stages for removal of tritium from wastewaters to MCL concentrations are liquid phase catalytic exchange (LPCE) with solid oxide electrolyte (SOE) or hot temperature electrolytic decomposition, membrane separation, Taser isotope separation, tritium removal by sulphur resin ion exchange, and metal hydride based isotope separation. None of these technologies are in commercial operation to remove tritium in wastewater to the MCL concentration. Parts of some of these technologies are in commercial use for producing tritium and/or deuterium products. These technologies are in various stages of development for wastewater treatment and some are currently being pursued by several interested parties. The processes considered, investigating company, brief process description and evaluation of these processes are shown in Table 3.

\subsubsection{Liquid Phase Catalytic Exchange with Solid 0xide Electrolyte}

The development of hydrophobic catalysts has stimulated an extensive research effort in the development of hydrogen isotope separation processes (Butler 1978 and 1980). LPCE, coupled with the use of a SOE, is a modestly energy-efficient process for reducing the tritium concentration in wastewaters below the MCL (Yamai 1995). Coupling the hydrophobic catalysts (as used in 
Table 3. Comparison of Group Two Development Processes to Separate Tritium from Water.

\begin{tabular}{|c|c|c|c|}
\hline Process: Status & Company/Lab: Contact & Process Description & Evaluation: Pros and Cons \\
\hline $\begin{array}{l}\text { LPCE with SOE or Hot Elly } \\
\text { Laboratory tested }\end{array}$ & $\begin{array}{l}\text { Jopen Atomic Energy Research } \\
\text { Karlsruhe, KFK }\end{array}$ & $\begin{array}{l}\text { Tritium exchange between } \mathrm{H}_{2} / \mathrm{HT} \text { and } \\
\mathrm{H}_{2} \mathrm{O} / \mathrm{HTO} \text { gas and water to remove } \\
\text { rritium from water feed stream using } \\
\text { wet-proof catalysts. Includes variations } \\
\text { of electrolytic cell/SOE cell/and } \\
\text { high-temperature steam electrolysis. }\end{array}$ & $\begin{array}{l}\text { Pro: Similar process used commercially to remove } \\
\text { tritium from heavy water. } \\
\text { Con: Needs improved catalyst and economics. } \\
\text { Needs demanstration on large scale. }\end{array}$ \\
\hline $\begin{array}{l}\text { Polysulfazone Membrane } \\
\text { Laboratory testing } \\
30 \% \text { separations in } \\
\text { singli-pass } \\
\text { with tritium }\end{array}$ & $\begin{array}{l}\text { Pacific Narthwest Laboratory } \\
\text { Richland, Washington }\end{array}$ & $\begin{array}{l}\text { Laboratory test tickets made from } \\
\text { substituted polyphosphazines. Water } \\
\text { passing through membrane at low-tritium } \\
\text { concentration had } 30 \% \text { less tritium than } \\
\text { feed. }\end{array}$ & $\begin{array}{l}\text { Pro: Capital and operating costs expected to be } \\
\text { similar to other membrane processes. Separation } \\
\text { takes place without a phase change. } \\
\text { Con: Process needs pilot scale demonstration. }\end{array}$ \\
\hline $\begin{array}{l}\text { Laser lsotope Separation } \\
\text { Extensive pilot-scale } \\
\text { development of all components } \\
\text { completed by } 1988 \text { at OHRD. } \\
\text { Laser photoreactor design } \\
\text { dovelopment stressed at RIKEN. } \\
\text { Theoretical two-phese photon } \\
\text { process laboratory tested but in } \\
\text { need of better laser tuning. }\end{array}$ & $\begin{array}{l}\text { Ontario Hydro, Research Division (OHRD) } \\
\text { 80o Kipling Avanue } \\
\text { Toronto, Ontario Canada } \\
\text { Applied Laser Chemistry Laboratory } \\
\text { The Institute of Physical and Chemical } \\
\text { Resoarch (RIKEN) } \\
\text { Wako-shi, Saitama } 351.01 \\
\text { Japan } \\
\text { Mound Laser and Photonic Center, Inc. } \\
\text { Miamisburg, Ohio }\end{array}$ & 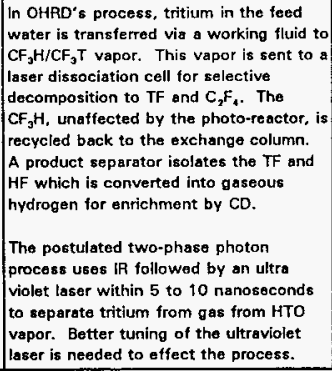 & $\begin{array}{l}\text { Pro: Enrichment factors of about 2, 5,000 have been } \\
\text { achieved. } \\
\text { Con: Process tested for feed water tritium } \\
\text { concentration six orders of magnitude higher than the } \\
\text { Hanford Site streams. Process effectiveness needs to } \\
\text { be tested at parts per trilion tritium levels. Flow } \\
\text { diagram needs to be revised because product } \\
\text { recovery is not aconomical st these concentrations. }\end{array}$ \\
\hline $\begin{array}{l}\text { Sulfur Rosin Exchange } \\
\text { Process in theoretical } \\
\text { stage devolopment }\end{array}$ & $\begin{array}{l}\text { Westinghouse Savannah River Co. } \\
\text { Aiken, South Carolina }\end{array}$ & $\begin{array}{l}\text { Sulfur resin would preferentially } \\
\text { exchange tritium with an existing } \\
\text { protium on H.S bond and load on resin at } \\
\text { near ambient temperature and pressure. } \\
\text { The tritium-sulfur bond strength is } \\
\text { gre ater than the protium-sulfur bond } \\
\text { strength. }\end{array}$ & $\begin{array}{l}\text { Pro: This process would not require a phase change } \\
\text { or be an energy intensive process. } \\
\text { Con: Only theoretical at this point and needs } \\
\text { laboratory testing. }\end{array}$ \\
\hline $\begin{array}{l}\text { Metal Hydride Catalyzed } \\
\text { Hydrogen Distillation } \\
\text { Tested on plant scale for } \\
\text { protium deuterium } \\
\text { separation }\end{array}$ & $\begin{array}{l}\text { Westinghouse Savannah River Co. } \\
\text { Savennah River Laboratory }\end{array}$ & $\begin{array}{l}\text { Reguires water to be converted to } \\
\text { hydrogen gas and then separated from } \\
\text { tritium by catalyzed hydrogen distillation. }\end{array}$ & $\begin{array}{l}\text { Pro: Has high-catalyzed separation factors for } \\
\text { separating tritium from protium. Demonstrated } \\
\text { process for separating deuterium from protium at } \\
\text { RTF. } \\
\text { Con: Need to canvert water to hydrogen gas for feed } \\
\text { to this process. Need pilot scalo demenstration. }\end{array}$ \\
\hline
\end{tabular}


LPCE) with a SOE has been demonstrated in Japan on a laboratory scale to be energy efficient and technically effective in reducing tritium concentrations in liquid water to below the MCL. This process also accumulates the collected tritium at manageable concentrations.

\subsubsection{Process Description}

This system consists of a stripping column, an enrichment column, and a solid oxide electrolytic cell as shown in Figure 2. An evaporator, two heat exchangers, a condenser and a cooler, and several liquid pumps are also included as part of the system. The solid oxide electrolyte operates at about $800{ }^{\circ} \mathrm{C}$ for conversion of HTO vapor to tritiated hydrogen (HT) gas and conversion of hydrogen gas to water vapor.

The liquid feed combined with the bottom-stripping column liquid is fed into the top of the enrichment column to contact HT gas flowing up through the column over a hydrophobic platinum catalyst bed. The bulk of the tritium in the tritiated gas is exchanged with hydrogen in liquid water in the presence of the hydrophobic platinum catalyst at ambient temperature. The hydrogen and HT gas leaving the top of the enrichment column is introduced at the bottom of the stripping column. Water low in tritium is fed to the top of the stripping column and contacts the hydrogen and residual HT gas flowing up through the column. The HT remaining in the gas stream is removed to form liquid HTO in the stripping column.

The HTO from the bottom of the enrichment column is vaporized in an evaporator and then contacted with a cathode next to a solid oxide electrolytic cell which removes oxygen from the HTO and passes it through the solid oxide cell. This oxygen then reacts with hydrogen gas from the top of the stripping column at the anode on the adjacent side of the solid oxide to form water vapor. Tritium is not transported through the solid oxide cell and thus the transported oxygen and the water formed on the anode side is essentially free of tritium contamination. This water vapor is condensed and the bulk of it discharged as detritiated water. A portion of this stream is routed back to the top of the stripping column for reuse as a stripping medium. A small portion of the HTO stream from the bottom of the enrichment column is drawn off as water enriched in tritium.

The system is operated under slight pressure to prevent air ingress which could combust with hydrogen in the system. A heater and insulation is used to control the solid oxide bed temperature at an operating temperature of about $800^{\circ} \mathrm{C}$. An organic absorber and demineralizer can be used on the water feed stream to help protect the catalysts from contaminants if necessary.

Calculations for performance of this system, shown in Figure 2, indicate that tritium concentrations can be reduced from a water feed concentration of $500 \mu \mathrm{Ci} / \mathrm{L}$ to a depleted stream concentration of about $5,000 \mathrm{pCi} / \mathrm{L}$. An enriched stream of about $0.05 \mathrm{Ci} / \mathrm{L}$ was produced in the iaboratory scale system using about $2 \mathrm{~L}$ of feed. The tritium inventory in the system is very much reduced below that in conventional water electrolysis systems.

\subsubsection{Application to Hanford}

This system appears promising due to its low energy consumption for operation and should be further considered for application at the Hanford site. However, the system would require considerable enlargement and further development, cost analyses, and demonstration prior to reliable application. 


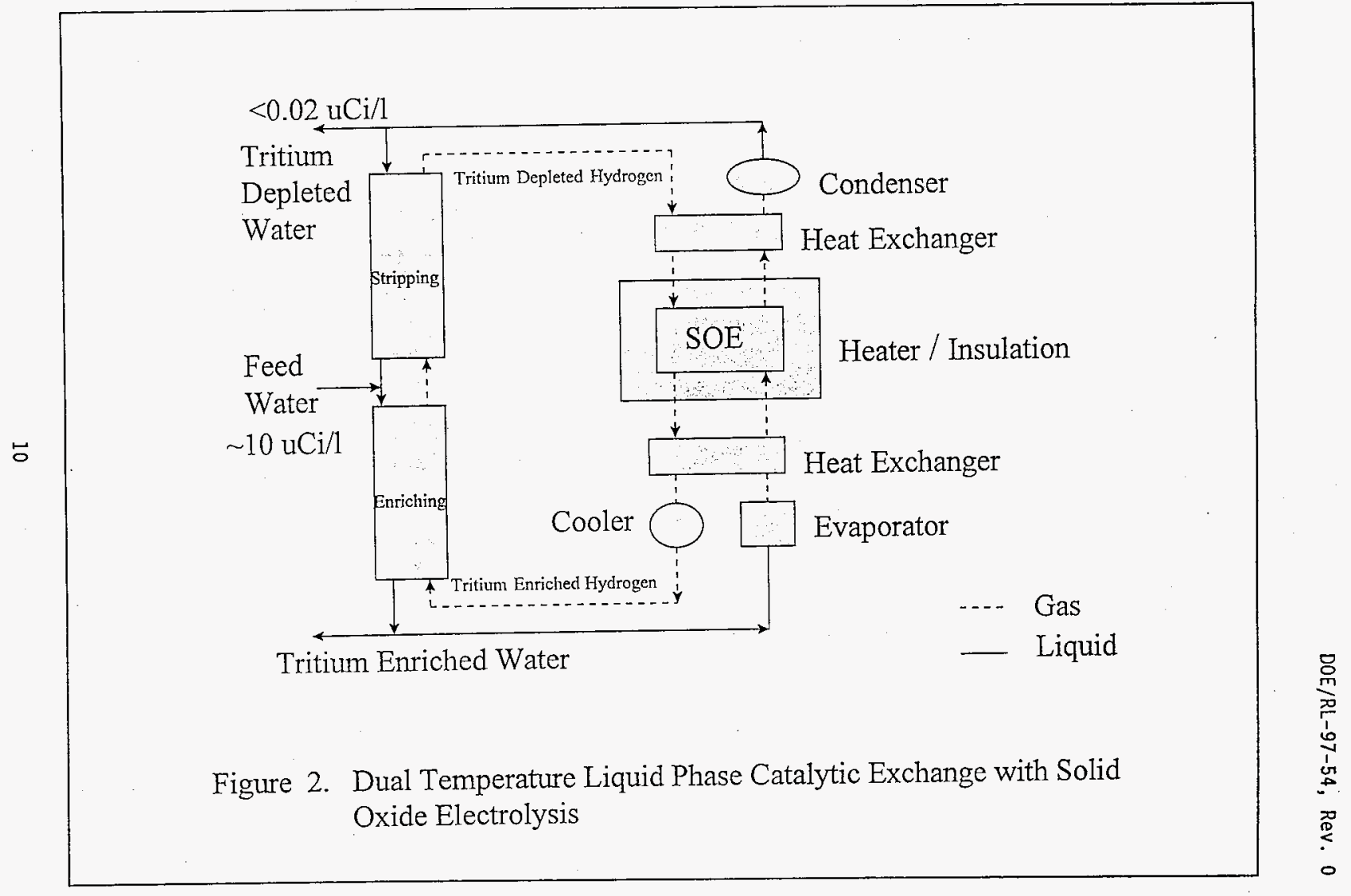




\subsubsection{Liquid Phase Catalytic Exchange with Hot Elly}

A combination of the LPCE with a high-temperature steam electrolysis (Hot E11y) process has been developed and demonstrated on a pilot scale for removing tritium from wastewater (Keil 1988). The process was developed to reduce the cost of electrolysis as part of conventional combined electrolysis catalytic exchange processes utilizing liquid water electrolysis.

\subsubsection{Process Description}

This process (as shown in Figure 3) includes a stripping column and an enriching column with the wastewater feed being introduced in the liquid stream between the two columns. Counter current flow of liquid down through the columns and HT gas up through the columns past catalyst beds allows the exchanging of tritium for protium with the enriched tritium stream being taped from the bottom of the enrichment column. The bulk of this tritium-enriched stream is routed to an evaporator and superheater where it is converted to steam at $900^{\circ} \mathrm{C}$ and then electrolyzed as a gas. The HT gas produced is cooled and returned to the bottom of the enrichment column. The oxygen produced is free of tritium and is partially used to fire the evaporator and superheater burners and the excess discharged to the atmosphere. The hydrogen gas stream coming from the top of the stripping column is depleted in tritium and is used to fuel the evaporator and superheater burners and the excess discharged to the atmosphere. A moderate amount of energy is needed to perform the electrolysis of the heated tritiated steam.

\subsubsection{Application at the Hanford Site}

This process has been demonstrated at a pilot plant scale at the German Nuclear Research Facility in Karlsruhe, KfK, Federal Republic of Germany (FRG). It requires less energy than conventional CECE processes but more then the LPCE with SOE process. This process also utilizes high-temperature streams and processing equipment which are of a safety concern when processing hydrogen and oxygen gas streams.

\subsubsection{Membrane Mediated Separation of Tritiated Water From Wastewater}

Membrane separation of HTO from protinated water $\left(\mathrm{H}_{2} \mathrm{O}\right)$ is based on an inorganic polyphosphazine polymer (U.S. Patent No. 5,451.322) with repeating monomeric units of:

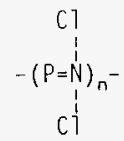

The chlorine atoms are replaced with organic pedant groups (phenoxy) and then $10 \%$ carboxyl groups are attached to the polymer. The polymer is dissolved in dioxane and solvent cast onto an anisotropic flat plate support web membrane. The membrane is allowed to dry at ambient temperatures and then is annealed overnight at $75^{\circ} \mathrm{C}$. The membrane was cut into circular test tickets, placed in a DeSal membrane test bed, and challenged with HTO. 


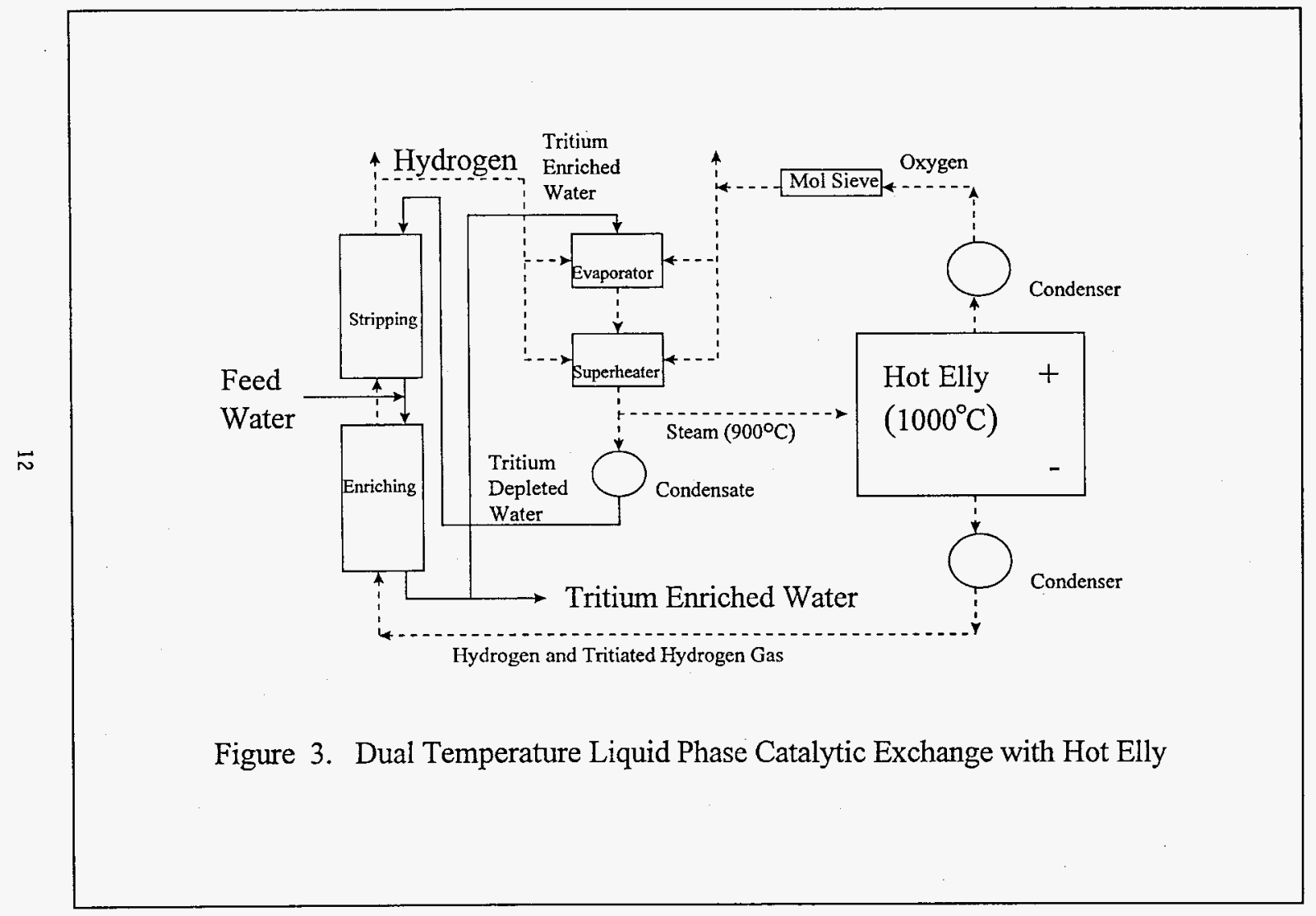




\subsubsection{Process Description and Test Results}

The membrane was tested with several liters of KE basin water with a tritium concentration of $3 \mu \mathrm{Ci} / \mathrm{L}$. The water was chilled to approximately $4{ }^{\circ} \mathrm{C}$ to maximize density, and the $\mathrm{pH}$ was held above 10 , as hypothesized to maximizing water clustering with the $0 \mathrm{~T}^{-}$. The pressure was maintained from 90 to 120 psi across the membranes during testing depending upon thickness of the solvent cast (at ambient conditions) membranes. The test unit was a flat bed pressurized cross-flow filtration unit and tested only the efficacy of the polymeric formulation. Utilization of this test bed is an industry accepted methodology for initial polymeric formulation testing. The membrane performed we 11 with average rejections of $20 \%$ with as much as 30 to $40 \%$, single pass (Figure 4). Average rejection refers to the entire run as replication, with individual points serving as tuples. The tritium was contained in the concentrate, not in the membrane. Experiments were conducted which indicate that there was no exchange of tritium for protium in the membrane, nor did it sequester itself within polymeric chains. The tritium concentration in the feed reservoir flask increased in concentration during the test. Membranes were tested several times with very little indication of degradation in performance. A membrane unit was not run until it failed.

No hydraulic data was obtained from this test stand. Hydraulic data must be determined from calculations or from testing small modular configurations. The latter being the preferred method. A larger coating capability than was available for testing to date is needed to provide sufficient-coated membrane to produce a small-coated membrane module sufficient for hydraulic testing in a specific configurations such as spiral wound, tubular, hollow fiber, etc. Involvement of a company such as Kodak, 3M, Dupont to make a commercial test unit which should have better performance. Coating windows need to be run, hopper design and polymer rheology determined, and support web identified. Then module calculations can be made and finaliy a module fabricated.

\subsubsection{Application to the Hanford Site}

There is enough process knowledge to go forward with fabricating modules. The various aspects needed to move to an industrial manufacturing base are present. The polyphosphazine is now produced by Dr. Debra Saez, Technically, Inc., in Boston, Massachusetts. There has been interest expressed by $3 M$ coatings to pursue the manufacture of membrane, and SpinTek ${ }^{\mathrm{TM}}$, Inc. has expressed interest in fabricating modules.

For this technology to be usable, a suite of coating development tests must be accomplished. Coating windows need to be determined for the most efficacious polymer formulation (10\% carboxypolyphosphazine). Coating windows entail a statistical derivation of a multi-factored design. For example, web speed, humidity, drying temperatures, drying times, hopper geometry, application direction, etc.

Funding is being sought to further develop and test this technology. Considerable development work is needed prior to application. No work is currently being done. 
D0E/RL-97-54, Rev. 0

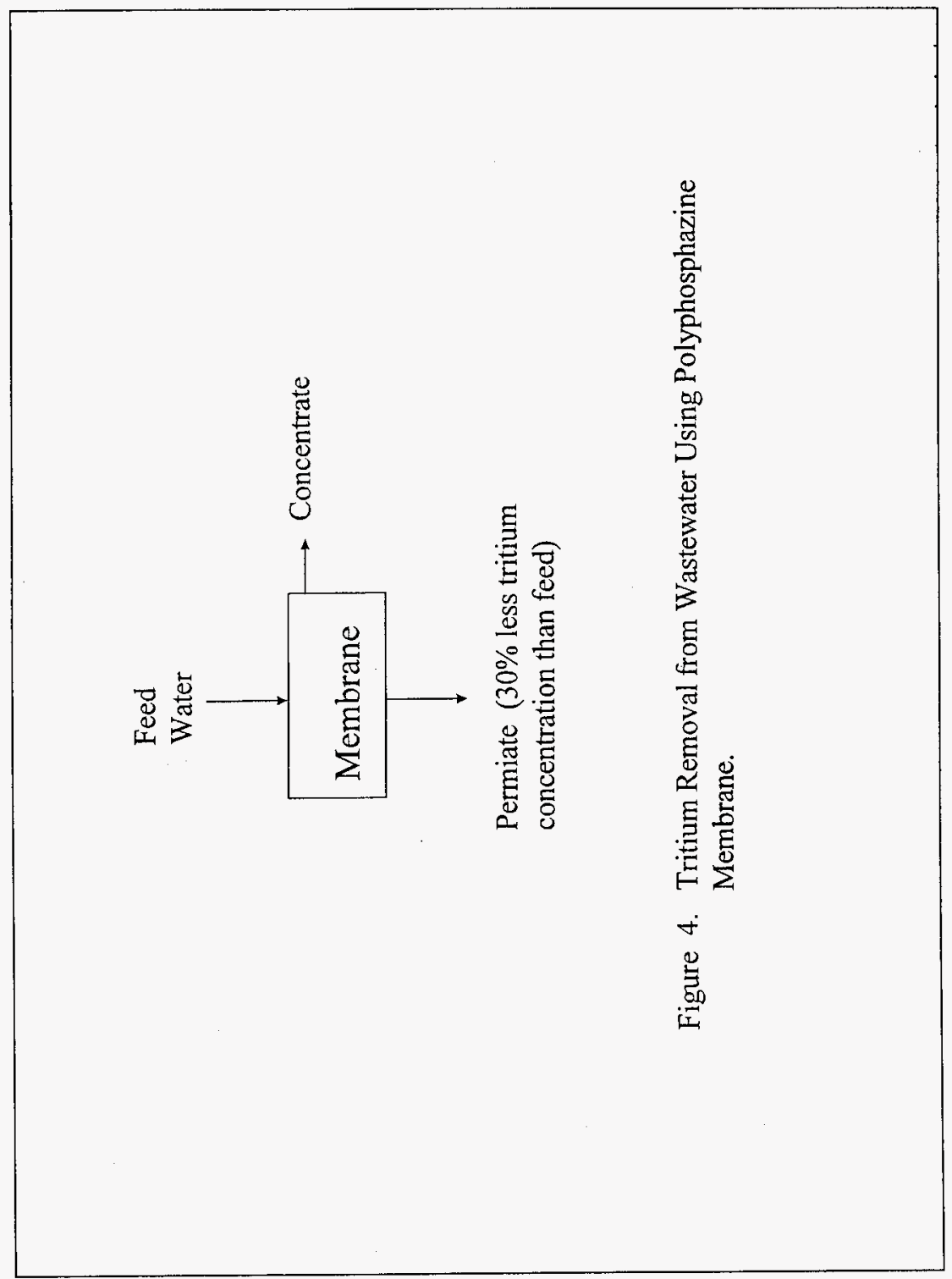




\subsubsection{Laser Induced Tritium Separation}

Conventional isotope separation methods utilize slight differences in some chemical or physical property, such as vapor pressure, and are more suited for streams with a high-tritium concentration (a few per cent) in the feed stream. Dilute streams $(<0.01 \% \mathrm{~T})$ may be more economically separated by a laser method exploiting the differences in vibrational frequencies of protonated and tritiated molecules. The required energy for the separation is directly related to the concentration of tritiated molecules present in trace amounts.

Early techniques proposed for tritium separation using lasers involved photolyzing the primary source of tritium, water (Evans). A two-step infrared (IR)/ultraviolet photo dissociation of HTO for tritium separation was tested in the mid 70 s (Figure 5). The isotopically selective absorption of the first step was destroyed due to the inefficient laser sources used resulting in poor photon utilization, and extremely fast vibrational relaxation in water vapor. Improvements in laser tuning which has occurred since the 70 's may make this approach more viable. However, there is no known development work being done to evaluate or develop that approach.

In another approach, Japanese, Canadian, and U.S. researchers chose a different hydrogen-bearing molecule as the photo-separable source of tritium for laser separation. This molecule, called the "working" molecule, was selected because it was able to pick up tritium from its original source, tritiated water (HTO), by rapid catalyzed 1iquid-phase hydrogen exchange, without being hydrolyzed.

The main investigators were three groups at: The Institute of Physical and Chemical Research (RIKEN) Wako, Saitama, Japan; Lawrence Livermore National Laboratory, Livermore, California, United States of America; and at Ontario Hydro Research Division (OHRD), Toronto, Ontario, Canada.

\subsubsection{Process Description}

Laser isotope separation of tritium has been described in considerable detail (Vasaru 1990, Bartoszek, et. a1. 1988). The method, as shown in the process diagram Figure 6 (Vasaru), utilizes IR 1aser-induced multiphoton dissociation (MPD), yielding a single-stage enrichment factor of over 10,000. The tritium in the feed water is exchanged with hydrogen in a gaseous working molecule $\mathrm{CF}_{3} \mathrm{H}$ by contacting the two streams in an isotope-exchange column. The CF $T$ formed is isotopically selectively dissociated in a laser cell specially designed for continuous operation. The gas-phase, pulsed IR-laser photolysis of only the tritiated molecule, leaves the transparent, major nontritiated species unchanged. The tritium-enriched photoproducts are removed from the gas stream by chemical and/or physical methods, and the remaining gas is recycled to the exchanger.

In the above method as shown in the RIKEN process schematic (Vasaru), the incoming wastewater does not need to be vaporized for laser separation of tritium. Tritium containing water exchanges tritium for hydrogen in the gaseous working substance counter currently. No boiler is necessary (Takeuchi 1997). 

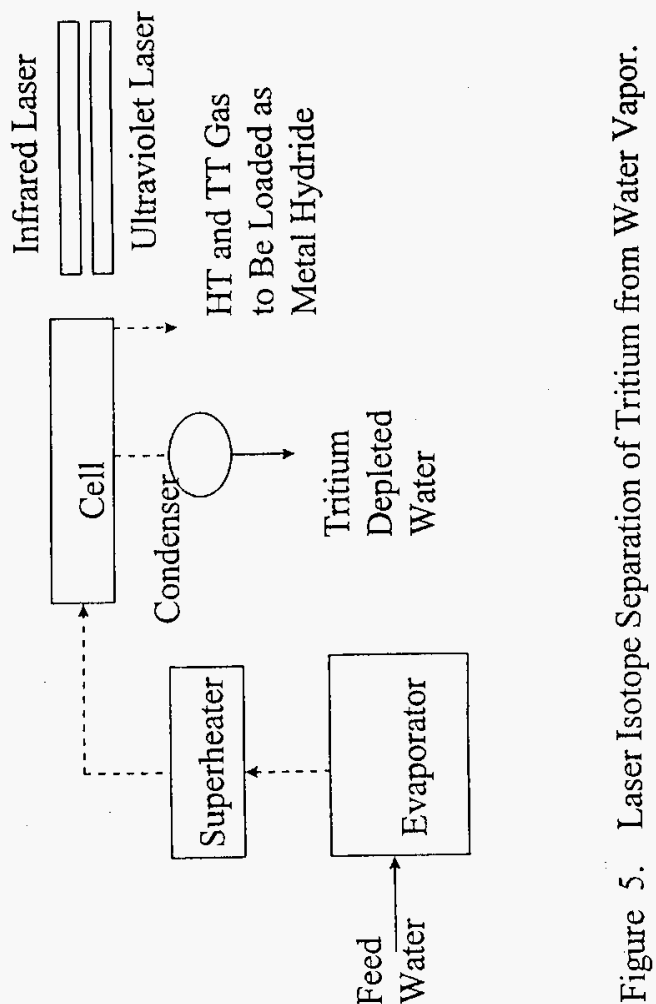


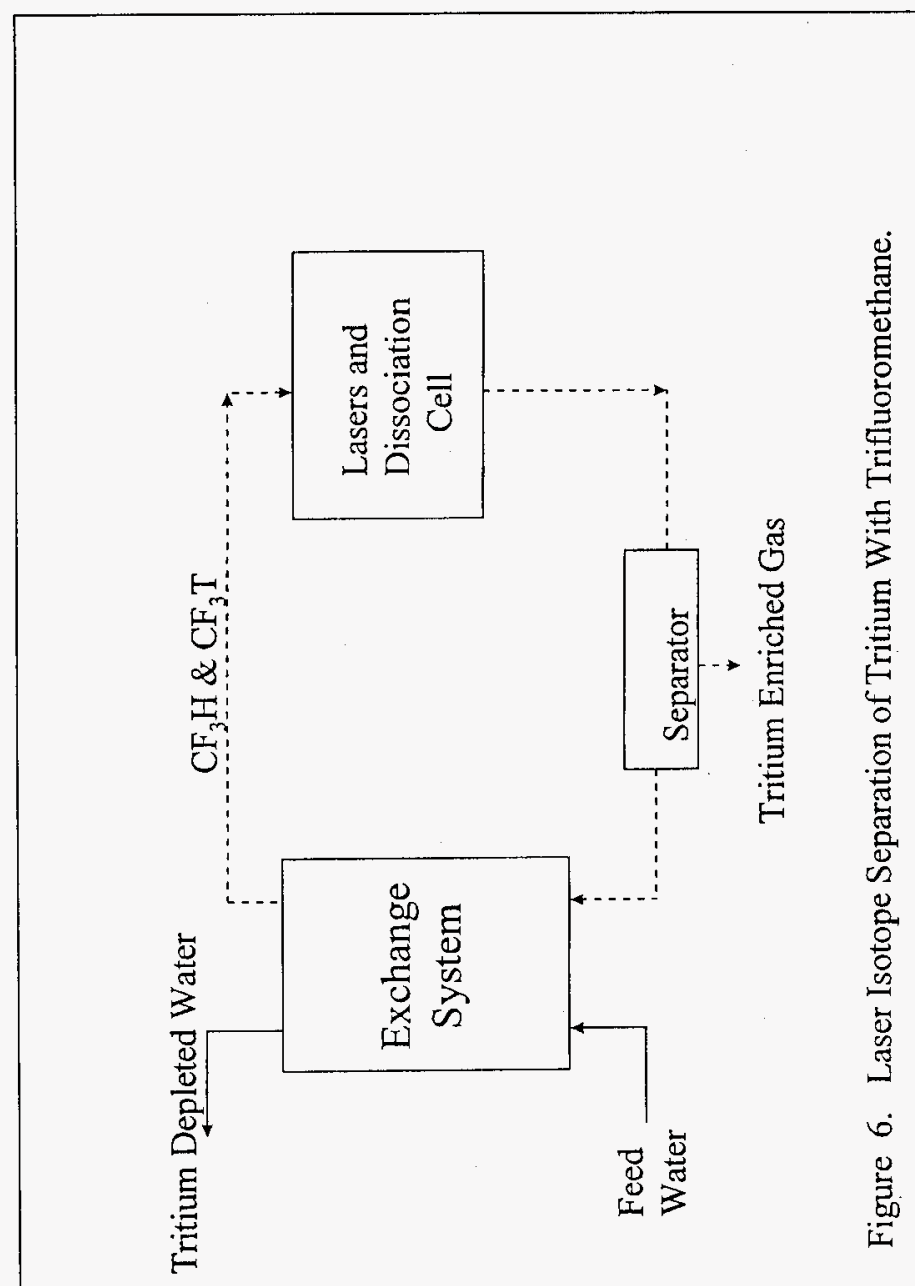


To enhance the utilization of laser energy in the first continuous reactor for laser tritium isotope separation, a new photo reactor design was satisfactorily tested (Takeuchi 1987) using the same working molecule, trifluoromethane. The new reactor had three compartments which were continuousiy stirred independently. The $\mathrm{CO}_{2}$ laser beam was sequentially focused with reduced focal length so that the focal fluence was kept at the optimum value.

In a chapter on laser methods in the book, "Tritium Isotope Separation," Vasaru 7 ists an abundance of papers published on laser research done at RIKEN. Much of the RIKEN effort was directed towards optimizing the laser parameters. Apparently (Wooda11), the rest of the equipment in their system needed further development.

Ontario Hydro of Canada developed and demonstrated all the components for a laser-based tritium isotope separation system based on tritium isotope exchange from water to trifluoromethane. In their process (Bartoszek et. al.), the input HTO is first boiled to steam which contacts an exchange liquid containing water, a rate-enhancing solvent dimethyl sulfoxide (OMSO), and the catalyst sodium hydroxide for tritiating trifluoromethane. The tritium in the steam exchanges with the hydrogen in the exchange liquid; the outgoing steam is depleted in tritium and after condensation becomes the treated water stream.

To avoid the need to recover DMSO, OHRD's process (Bartoszek, et. a1.) uses two exchange towers which allows equilibration of gas and liquid streams. The second exchange tower transfers the tritium from the exchange liquid to trifluoromethane gas stream which is converted to $\mathrm{CF}_{3} \mathrm{~T}$. The process gas then passes through the dissociation cell where the $\mathrm{CO}_{2}$ laser beam selectively dissociates the $C_{3} T$ into tritium fluoride (TF) and $C_{2} F_{4}$. Process development at OHRD continued with a product separator and CD to recover tritium.

\subsubsection{Economics and Applicability for Hanford}

In principle, laser isotope separation is efficient at any tritium level because the energy required for the separation is directly used for the dissociation of the tritium containing substance. Since the molecules containing only protium do not absorb the laser light, the energy is not wasted. The tritium to protium $(T / H)$ ratio in experiments performed at RIKEN was typically of the order of 1 ppm or less.

The tritium concentration in the streams to be treated at Hanford is several orders of magnitude lower. It ranges downward from a maximum of about $1.5 \mathrm{ppt}$, i.e., $14 \mu \mathrm{C} \mathbf{i} / \mathrm{L}$ (found in spent fuel pools at Hanford). The treated stream concentration target is $0.02 \mu \mathrm{Ci} / \mathrm{L}$, MCL concentration. This application would require some research and development effort before a feasibility study is undertaken. The average power of the laser required will need to be estimated. This is a new process and is not ready for an engineering company to build a plant based on past bench-scale experiments.

One feature of tritium separation using lasers is the need to introduce a rate enhancing solvent, dimethylsulfoxide and a catalyst sodium hydroxide which forms a part of the exchange liquid. In addition, the trifluoromethane comes in intimate contact with the water stream and in spite of best controls, a portion of all added chemicals will exit with the treated water stream as a contaminant. 
For reasons similar to those stated above, the status report (Fulbright et. al.), covering detrition strategy for environmental remediation for the Savannah River Site has not selected the laser separation method for full evaluation. A similar technology survey report from Lawrence Livermore Laboratory (Mcconachie) has not included laser isotope separation among the seven treatment methods discussed in the report.

A review article, "Laser Separation of Tritium," by Takeuchi and Herman was published in, "Laser Applications in Physical Chemistry." These renowned researchers of this technology, state (Evans) the need for developmental work before this process is deployed on a large scale. Modeling studies have been recommended to establish the relationship between multiphoton dissociation and process feed and product flows, and isotopic exchange rates. Optimization of photoreactor design for high enrichment is needed to produce the largest yield of tritium for the fewest laser photons. Finally, integration of the laser design with the photoreactor is important. Although, no cost comparisons for this method were made with other more developed technologies, these researchers qualitatively state that it is expected that laser separation will be competitive.

Given the current state of development of the laser isotope separation method for tritium, it is apparent that this process is not ready for deployment in treating the Hanford effluent water streams. Past research has focused on feed water with tritium levels several orders of magnitude higher than in the Hanford application.

Evaluating the effectiveness of lasers with levels of tritium in Hanford streams would require further laboratory experimentation. However, there is no basic research $\mathrm{planned}$ and no new pertinent experimental data has being generated for almost a decade. Although the laser method has promise, it appears that a substantial commitment of research funds would be needed, followed by scale-up studies for process development and design. In an era of tight schedules and competitive budgets, further interest for applying this technology does not appear likely to be forthcoming.

\subsubsection{Tritium Removal from Wastewater Using Sulfur Resin Ion Exchange}

An invention disclosure has been submitted for a sulfur resin ion exchange process to remove tritium from wastewater (Lee 1997). Theoretical evaluations have been made which indicate that tritium could be removed from HTO with a sulfur resin. This process utilizes the exchange capability of tritium to replace protium from existing $\mathrm{H}$-S bonds to load tritium on sulfur resin. This process would occur at near ambient temperatures and pressure. A proposal for funding has been submitted to do laboratory work for theory verification. The loaded sulfur resin may be dispositioned in an appropriate waste form such as grout at a relatively low cost.

\subsubsection{Process Description}

This process has not been demonstrated yet but is proposed to consist of a sulfur resin bed which would have tritiated wastewater flow through the bed at near ambient temperature and pressure. Tritium would be preferentially loaded on the bed by tritium exchange with protium for a resin protium-sulfur bond (Figure 7). There are commercially available resins with protium-sulfur bonds which could be tested for effectiveness of this process at small costs. The loaded resin could be removed from the column and grouted for disposition. 
DOE/RL-97-54, Rev. 0

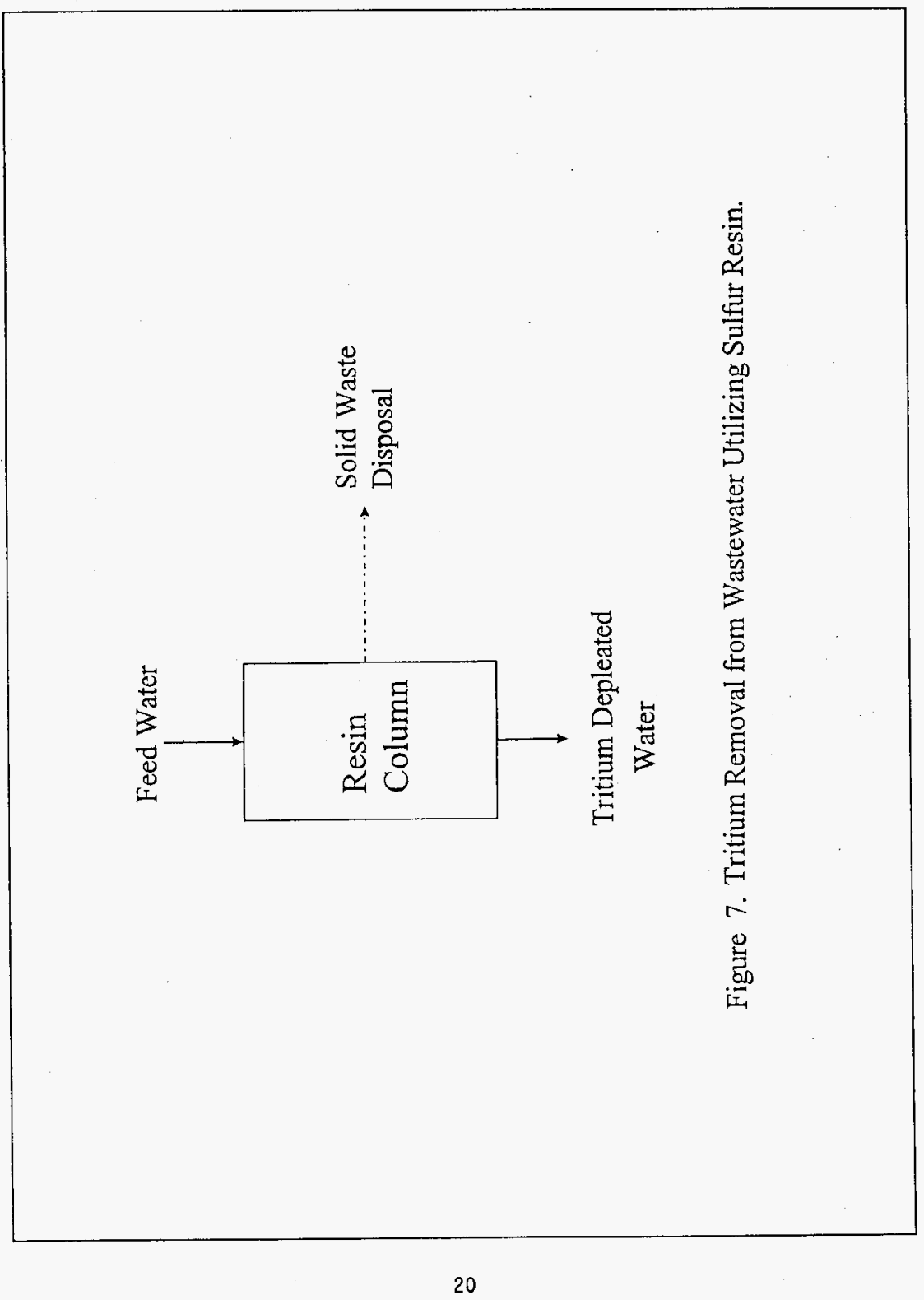


DOE/RL-97-54, Rev, 0

\subsubsection{Application at the Hanford Site}

It would be necessary to demonstrate that this process could remove tritium to less than the $\mathrm{MCL}$ concentration of $0.02 \mu \mathrm{Ci} / \mathrm{L}$ and that an acceptable waste form could be produced. This concept may have the potential to remove tritium from wastewaters at a much reduced cost than conventiona? methods. A proposal has been submitted for funding to demonstrate the process on a laboratory scale.

\subsubsection{Tritium Removal from Wastewater Using Metal Hydride Exchange}

Metal hydride based isotope separation by catalyzed hydrogen distillation using palladium coated on Kieselguhr ( $\mathrm{Pd} / \mathrm{K}$ ) as the active packing material has been recently developed and is being used to separate protium and deuterium (Horen 1992, Anderson 1995). This process is named thermal-cycling absorption process (TCAP). Single-stage separation factors of tritiated hydrogen from protium $(\mathrm{HT} / \mathrm{H})$ for this process are temperature-dependent ranging from about 1.5 at $600{ }^{\circ} \mathrm{K}$ to 4.5 at $200^{\circ} \mathrm{K}$ in the presence of the palladium hydride. This process was demonstrated to separate protium from deuterium and is more effective for separating tritium from protium because the separation factors are greater by a factor of about 1.6 for a given temperature. A hydrogen gas stipping column would need to be used in conjunction with this process to strip tritium from the wastewater to form HT gas which could be processed through the metal hydride exchanger. This process is being used at the Replacement Tritium Facility (RTF) for separating tritium product from protium and deuterium and is reported to be less costly than cryogenic distillation.

\subsubsection{Process Description}

The TCAP is a semi-continuous gas chromatographic separation process consisting of a Pd/K-packed column and a larger column filled with Kieselguhr called the plug flow reverser (PFR) as shown in Figure 8 . Hot or cold nitrogen gas passes through the shell surrounding the Pd/k-packed coil to heat or cool the metal hydride, which desorbs or absorbs hydrogen isotopes. The tritiated feed gas would be fed into the middle section of Pd/k column. Hydrogen isotopes are loaded on the packing at different rates. The lighter isotopes absorb first and the heaver isotopes 7 ater. This effect increases as temperature decreases. The loaded gases are moved back and forth from the $\mathrm{Pd} / \mathrm{k}$ column to the PFR column by adjusting temperatures to effect flow with minimal mixing.

A concentration profile develops along the Pd/k bed with protium on the top portion and tritium on the bottom portion. The raffinate (protium) would then be extracted from the top as hydrogen gas and the tritium would be withdrawn from the bottom as HT and tritium gases which could be loaded on a metal as hydride.

\subsubsection{Application to the Hanford Site}

This process would need a hydrogen gas feed stream which could be delivered by using a catalyzed hydrogen gas stripping column to remove tritium as HT from the wastewater. The protium gas raffinate from the Pd/K column could be used to supply this hydrogen gas. The metal hydride-based isotope separation system with the $P d / k$ column and PFR columns are compact. The total process would have to be demonstrated but the individual parts of the process have been demonstrated to perform independently. 
DOE/RL-97-54, Rev. 0

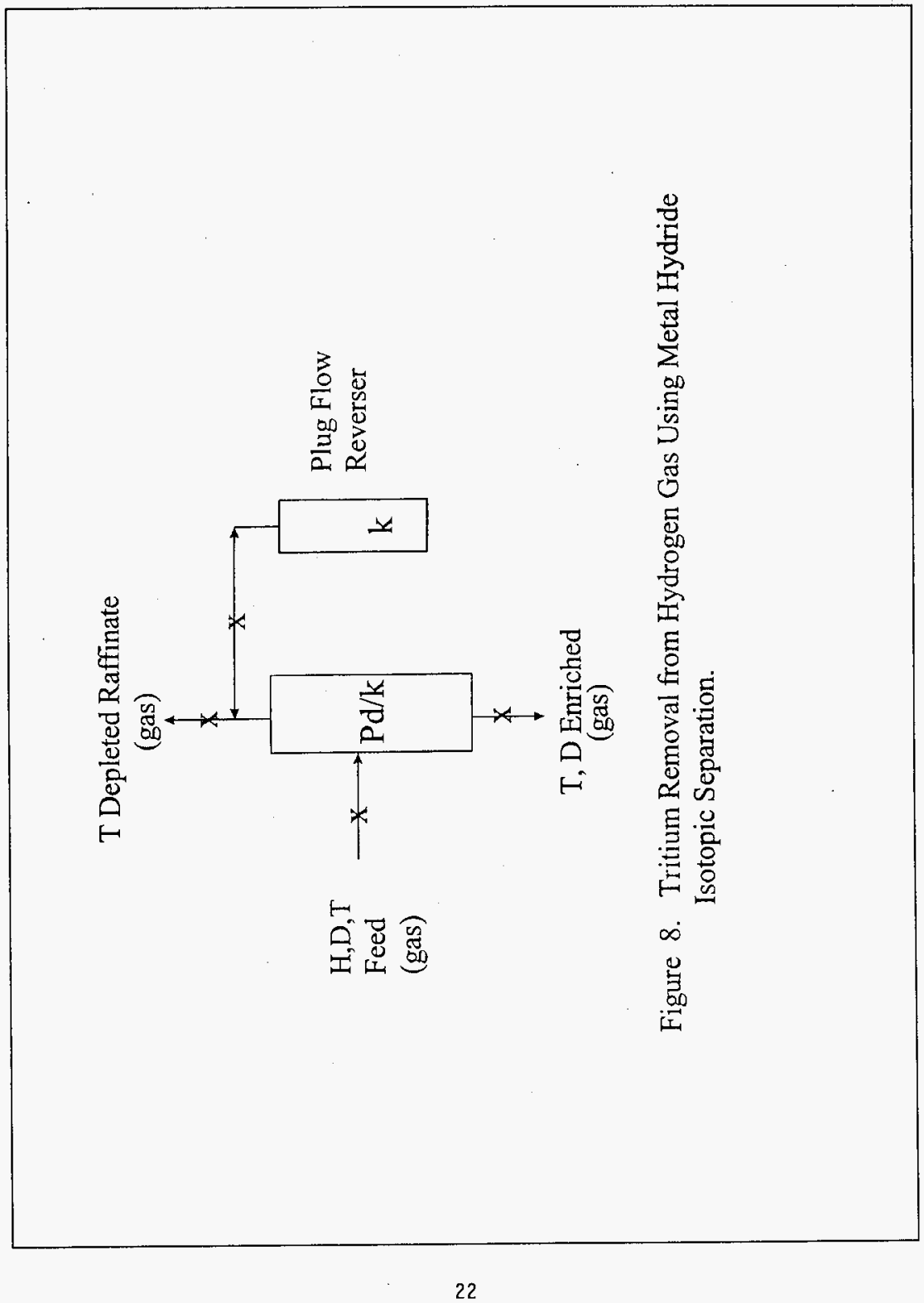




\subsection{GROUP THREE MITIGATION TECHNIQUES FOR TRITIUM IN GROUNDWATER}

Group three includes mitigation techniques for tritium isolation, decay, and/or removal. These techniques include the routing of future process condensates containing tritium to a perched location just outside the 200-West Area for natural decay, establishing tritium barriers by targeted freezing, concrete, or metal, and air sparging to remove tritium from the groundwater.

Tritium is migrating near the Columbia River at concentrations above the MCL. Analysis of well samples near the river by the old Hanford townsite indicate tritium concentrations greater then $180,000 \mathrm{pC} / \mathrm{L}$. This tritium in the groundwater came from the 200-East Area process condensates which have a flow to the river life of 23 years for this location.

Current ETf condensates being discharged into the ground are projected to contain process tritium discharges unti? the year 2025. Current tritium discharges are considerably less than when the separations plants were being used to process spent fuels.

\subsubsection{Permitted Discharge}

Current operation of the ETF includes effluent discharge (starting December 1995) to a state-approved land disposal site (SALDS) north of the 200-West Area. The decision to discharge to this location was made after several potential discharge sites were evaluated, both in the 200-East and 200-West Areas of the Hanford Site. The evaluation process. for locating the SALOS was conducted with the objective to minimize potential environmental impacts to the public and the environment. Consideration was given to locate the SALDS in an area that would provide the least likelihood for mobilization or re-mobilization of existing underground water plumes and contamination.

The aquifer below the discharge site has been the focus of significant numerical modeling efforts to evaluate the facility's potential effects on the entire aquifer between the SALDS and the Columbia River. The modeling results (Hartman 1997) showed that the aquifer was capable of providing the necessary residence time in order to allow for decay of the tritium to levels below the interim drinking water standards (regulatory concern) $(20,000 \mathrm{pC} i / \mathrm{L})$ prior to flow to the river. Eighty-years residence time is required at this site to allow tritium decay below levels of regulatory concern at its point of discharge. Further modeling efforts are currently underway to verify the results of the original model and to incorporate operational data collected during initial operation of the facility. Preliminary results predict an aquifer residence time much greater than 80 years prior to flow to the river. Restrictions on 7 and usage and continued groundwater sampling and monitoring will be needed during this 80-year residence time (Hartman 1997).

The rational for this option is to allow continued waste operations while discharging the liquid effluents into a limited aquifer. This aquifer is thought to not drain to the Columbia River and is expected to retain the tritium until it decays to below the $M C L$ concentration. Process condensates from treating high-level waste and fuel storage basin water are planned on being discharged to this location. A decay time of 80 years will be required for the tritium in this liquid to decay below the MCL. The disadvantage is that partial control of this land will be required for this time period. 


\subsubsection{Barrier Formation}

Barrier formation by freezing (Gates 1995) part of the underground water formation at strategic locations to prevent further tritium migration toward the Columbia River is a possibility. This technique could contain the tritium until it decays to below the MCL. This technique would require installation of an underground piping system and continuous energy input for a number of years. This technology is in use in several industries and is considered moderately costly to prevent tritium flow to the river.

The construction of a physical water barrier such as concrete or metal wall in strategic locations would require a large capital investment but require little operating costs.

\subsubsection{Air Sparging}

Air sparging studies were conducted on a pilot field-scale during 1996 to evaluate the potential for removal of tritium from HTO (Russel 1996). The two field tests demonstrated that tritium removal rates were $60 \%$ during a 31 -day test and $66 \%$ for a 23-day test. Air was sparged into 36,000 L of HTO $(160,000 \mathrm{pC} i / L)$ in an open tank during a period in which the outside mean temperature was $25.2{ }^{\circ} \mathrm{C}$. At the end of this first test, the tritium concentration was reduced to about $105,000 \mathrm{pCi} / \mathrm{L}$. The second test was conducted similarly except the mean temperature was $29.9^{\circ} \mathrm{C}$, the starting concentration was $220,000 \mathrm{pCi} / \mathrm{L}$ and the ending concentration was $132,000 \mathrm{pC} \mathbf{i} / \mathrm{L}$. Comparisons to previous laboratory work indicated that these rates could have been improved by utilizing smaller bubbles and providing a longer bubble path. Air sparging for long periods of time required considerable energy.

It was noted that increased exposure risks were prevalent the closer one worked to the experiments. The tritium is essentially removed as HTO vapor and discharged into the atmosphere. The benefits of this process would have to be clearly defined and risks assessed prior to application. It does not appear to be an acceptable practice to discharge tritium to the atmosphere as water vapor.

\subsection{TRITIUM AT THE HANFORD SITE}

Tritium has been generated as a byproduct in reactor fuel at the Hanford Site by nuclear reactor operations from 1944 to 1989 in support of the U.S. Defense Program and for steam production for electric power generation. Tritium was produced in the Hanford reactors by uranium and plutonium ternary fissioning (fissioned nucleus splits into three parts) and as an activation product from neutrons interacting with low-atomic mass impurities (elements such as lithium, boron, beryllium, and nitrogen) in the reactor core and deuterium and nitrogen impurities in cooling water one atom of tritium is generated for every $1.25 \times 10^{4}$ acts of fission in ${ }^{235} \mathrm{U}$ and for every $1.41 \times 10^{4}$ acts of fission in ${ }^{233} \mathrm{U}$. Tritium was also produced in the reactor cooling water from neutron capture by deuterium and by neutron splitting of nitrogen. Quantities of tritium produced in reactor fuel ranged from about $10 \mu \mathrm{Cj} / \mathrm{MTU}$ to $50 \mu \mathrm{Ci} / \mathrm{MTU}$ (Origin Code) depending upon fuel type and exposure. The total. tritium produced in the Hanford reactor fuels from 1944 to 1989 was estimated to be $1 \times 10^{8} \mathrm{Ci}$. The bulk of the tritium produced in the reactor 
remained/remains in the fuel elements until fuel reprocessing and about $1 \%$ of the reactor tritium exited in the reactor cooling water.

Tritium was released to the environment from the reactors, separations plants, and waste management operations in liquid discharges as HTO and in gas discharges as HT. The majority of the tritium released to the environment was from fuel separations facilities (PUREX, REDOX, and the two Bismuth Phosphate Plants: T-Plant and B-Plant) on the 200 Area plateau. Most of the tritium in the fuel (about 90\% for zirconium clad fuel) exited the separations plants in process condensate streams as HTO to cribs and ponds (Jeppson 1973). Approximately $5 \%$ of the tritium was released to the atmosphere in the dissolver offgases as HT. The other approximately $5 \%$ tritium was transferred to the Waste Fractionization Facility and tank farms as HTO in high-level waste. Much of the tritium transferred to waste fractionization and tank farms was discharged to cribs as process condensate from the waste fractionation and tank farm waste concentration processes. A similar split of tritium while processing aluminum clad fuel is expected to have occurred at PUREX. However, for the bismuth phosphate process which processed aluminum clad fuel, much more of the tritium would have gone to the waste tanks from the separations plants. Much of this tritium was then discharged to the cribs from the tank farm operations, U-Plant processing to recover uranium, and the ferrocyanide scavenging process to precipitate cesium, strontium, and cobalt.

Since the last reactor fuel was processed through PUREX in 1989, tritium releases to the environment have greatly decreased. There are presently tritium discharges to the ground with process condensates from tank farm waste processing. Most of the tritium currently released in liquid discharges goes to the SALDS site just north of the 200-West Area.

Total tritium generated at the Hanford Site production reactors is estimated to be $10.6 \mathrm{~kg}$ or $1.01 \times 10^{8} \mathrm{Ci}$ (Roblyer 1994). Most of this tritium was product tritium that was shipped offsite as target material. Tritium in fuel elements processed or stored at Hanford is estimated (Robyler 1997) to amount to a 1997 decayed value of $2.0 \times 10^{5}$ ci $(21 \mathrm{~g})$.

\subsection{TRITIUM IN PROCESS LIQUIDS}

Tritium is in the waste in the single-shell and double-shell underground storage tanks at the Hanford Site. Tritium is in the fuel storage basin waters at 105-KE, 105-KW, and 100-N. The quantities of tritium at these locations are listed in Table 4. The tritjum in the 105-KE basin water is not expected to increase because all of the canisters are open and the tritium has been free to disperse throughout the basin water. The tritium in the $105-\mathrm{KW}$ basin is presently at $0.07 \mu \mathrm{Ci} / \mathrm{L}$ but is expected to increase to about $1 \mu \mathrm{C} i / L$ when all of the canisters are opened to allow the fuel to be transported to a new storage location. The volumes of supernatant and associated tritium concentrations for 14 double-shell tanks are listed in Table 5 . 
Table 4. Estimated Tritium Inventories in Process Liquids at the Hanford Site.

\begin{tabular}{|l|c|c|c|}
\hline Process Liquid Location & $\begin{array}{c}\text { Approximate Tritium } \\
\text { Concentration } \\
(\mu \mathrm{Ci} / \mathrm{L})\end{array}$ & $\begin{array}{c}\text { Approximate } \\
\text { Associated } \\
\text { Volume } \\
\text { (liters) }\end{array}$ & $\begin{array}{c}\text { Tritium } \\
\text { (Ci) }\end{array}$ \\
\hline SSTs supernatant & $\sim 1$ & $1 \times 10^{9}$ & $\sim 1000$ \\
\hline DSTs supernatant & 2 to 38 & $5.3 \times 10^{8}$ & $\sim 2600$ \\
\hline $\begin{array}{l}\text { KE fuel basin water (a11 } \\
\text { canisters are open) }\end{array}$ & 2.86 & $4.5 \times 10^{6}$ & 13 \\
\hline $\begin{array}{l}\text { KW fue basin water } \\
\text { (expected vailue when al] } \\
\text { Canisters are opened) }\end{array}$ & $1-\begin{array}{c}\text { presently at } \\
0.07\end{array}$ & $4.5 \times 10^{6}$ & 5 \\
\hline \begin{tabular}{l} 
N fuel basin water \\
\hline
\end{tabular} & 14 & $4.2 \times 10^{6}$ & 56 \\
\hline
\end{tabular}

\subsection{GROUNDWATER SAMPLING}

Hanford site groundwater samples are taken, analyzed, and results reported annually. The most current results of these groundwater samples are reported in Dressel (1996). Tritium is the radionuclide which is most frequent $7 y$ analyzed in the groundwater samples because it was present in many of the liquid waste streams discharged to the ground and is a very mobile radionuclide in the groundwater.

About 800 wells at the Hanford Site are sampled in 1996 and about 500 of these were analyzed for tritium (Chamness and Merz 1997, Hartman and Dressel et. al. 1997). A map showing the location of these wells is shown in (Hartman and Dressel et. al. 1996, Plate 1). Samples are generally taken only from the top of the aquifer in each sampling well. Most of these sampling wells are screened in the uppermost aquifer near the water table, which lies from $10 \mathrm{~m}$ beneath the surface in the 100 Area, to $100 \mathrm{~m}$ beneath the surface in the 200 Area.

\subsection{TRITIUM IN GROUNDWATER}

A historical progression of the movement of groundwater plumes containing tritium from 1974 to 1996 is shown in Figure 9 as taken from Dirks 1994 and Hartman 1997. It indicates the effects of tritium decay and its rate of movement in the aquifer. It does not indicate a tritium profile depth in the aquifer. Separate tritium plumes exist in and/or emanate from the 100 and 200 Areas. Ranges of tritium concentrations at various locations on the Hanford Site and underground plume surface areas are listed in Table 6.

The change in tritium concentration in plumes where discharge of tritium effluents have been terminated are noted to decrease at a rate greater than the tritium decay rate (tritium decay half life of 12.3 years) as shown in Figure 10. Figure 10 shoes the tritium concentration trend in wel1 299-W22-9 located in the 200-West Area northeast of the REDOX Facility. This data over a 20-year period implies that dilution of tritium is occurring as well as tritium decay. 
Table 5. Tritium Concentration and Supernantant Volume in Some Double Tanks.

\begin{tabular}{|c|c|c|c|c|c|}
\hline Tank & Supernate & Sludge & $\mathrm{H} 3$ & $\mathrm{H} 3$ & Reference \\
\hline & Volume & Volume & $\begin{array}{c}\text { Supernat } \\
\mathrm{e}\end{array}$ & Solids & \\
\hline & $(L)$ & (L) & $(\mathrm{C} i / L)$ & $(\mathrm{Ci} / \mathrm{kg})$ & \\
\hline AP102 & $4.18 e+06$ & & $1.30 \mathrm{e}-05$ & & $\begin{array}{l}\text { WHC-SD-WM-ER-358 (TCR,94). Value was rejected } \\
\text { due to high analytical error estimate of } 76 \% \text {. }\end{array}$ \\
\hline AP101 & $4.01 \mathrm{e}+06$ & & $2.10 \mathrm{e}-06$ & & WHC-SD-WM-ER-357 (TCR,94). \\
\hline AP103 & $4.28 \mathrm{e}+06$ & & $5.24 \mathrm{e}-06$ & & WHC-SD-WM-ER-359 (TCR, 94) \\
\hline AP105 & $3.11 e+06$ & & $3.87 \mathrm{e}-06$ & & WHC-SD-WM-ER-360 (TCR, 94) \\
\hline AP107 & $4.19 \mathrm{e}+06$ & & $3.52 \mathrm{e}-05$ & & WHC-SD-WM-ER-362 (TCR,94) \\
\hline AW105 & $2.42 \mathrm{e}+05$ & $1.12 \mathrm{e}+06$ & $6.24 \mathrm{e}-05$ & $1.11 \mathrm{e}-05$ & WHC-SD-WM-ER-364 (TCR,94) \\
\hline AP106 & $4.27 e+06$ & & $4.90 \mathrm{e}-06$ & & WHC-SD-WM-ER-361 (TCR, 94) \\
\hline AN106 & $3.67 e+05$ & & $2.68 \mathrm{e}-06$ & & (Hendrickson 1994) \\
\hline AW101 & $3.83 e+06$ & & $5.90 e-06$ & & (Hendrickson 1994) \\
\hline AN103 & $3.55 \mathrm{e}+06$ & & $2.44 \mathrm{e}-06$ & & (Hendrickson 1994) \\
\hline AN102 & $3.76 \mathrm{e}+06$ & $3.37 \mathrm{e}+05$ & $1.77 \mathrm{e}-06$ & $3.50 \mathrm{e}-07$ & $\begin{array}{l}\text { Letter Report - Results of the Charac. of } \\
\text { Smples of Waste from DSTs 101AZ, 102AZ, 102AN, } \\
\text { (Tingey, 91) }\end{array}$ \\
\hline AWI 03 & $5.75 e+05$ & $1.37 e+06$ & $5.86 e-06$ & $2.69 \mathrm{e}-06$ & $\begin{array}{l}\text { Characterization of Waste from DST 103-AW, } \\
\text { (Tingey, et. al, September, 1990) }\end{array}$ \\
\hline AZ101 & $3.53 e+06$ & $1.32 \mathrm{e}+05$ & $3.76 e-05$ & $4.59 e-05$ & $\begin{array}{l}\text { D.E. Place Spreadsheet. Values based on core } \\
\text { samples and ORIGEN runs. }\end{array}$ \\
\hline$A Z 102$ & $3.27 \mathrm{e}+06$ & $3.68 \mathrm{e}+05$ & $2.07 e-05$ & $2.04 \mathrm{e}-05$ & $\begin{array}{l}\text { D.E. Place Spreadsheet. Values based on core } \\
\text { samples and ORIGEN runs. }\end{array}$ \\
\hline
\end{tabular}




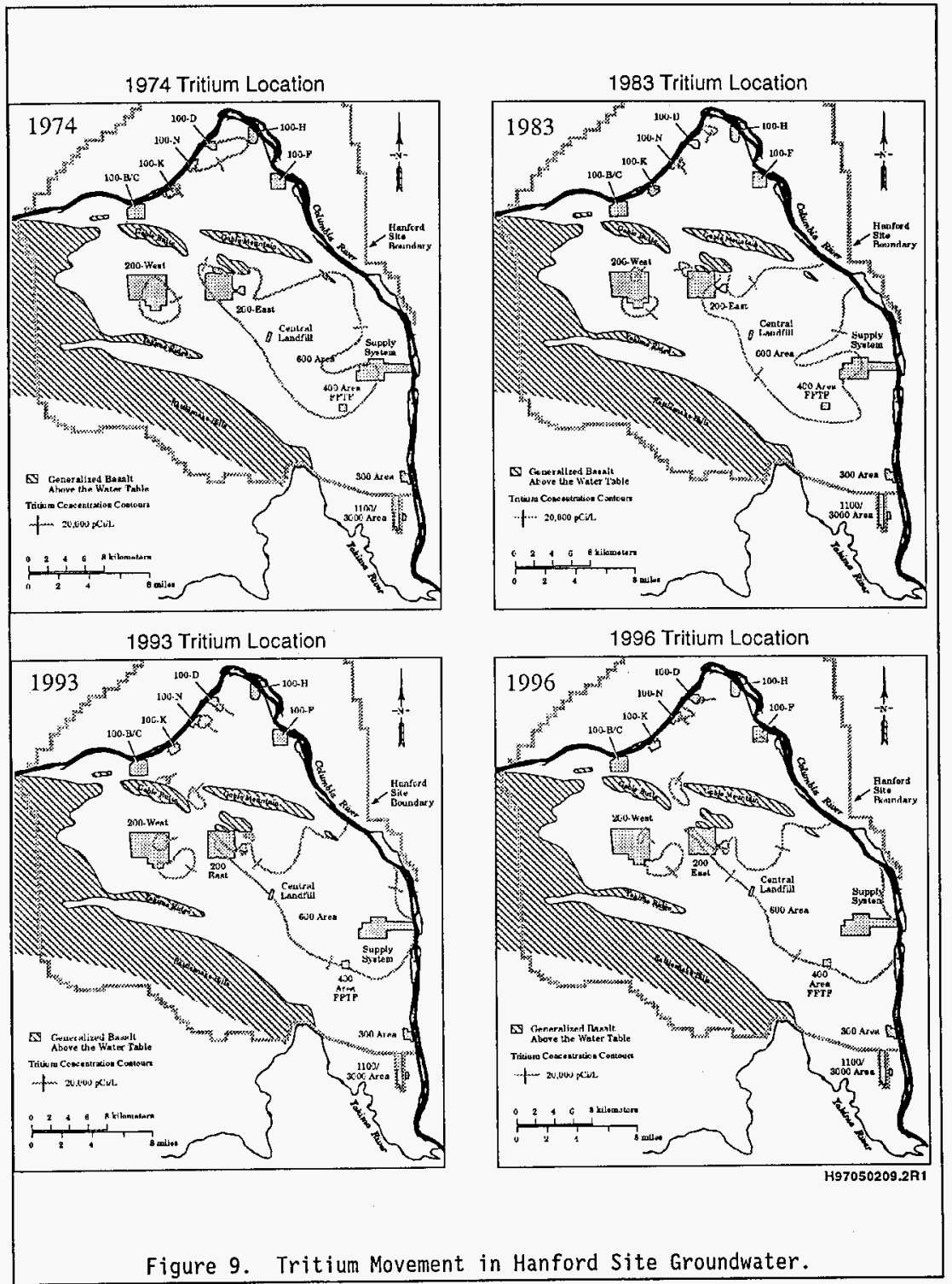


Table 6. Tritium Concentrations and Approximated Areas of Hanford Site Aquifers at $20,000 \mathrm{pCi} / \mathrm{L}$ or Greater.

(Values determined from Hartman et. a1. 1997)

\begin{tabular}{|l|c|c|}
\hline \multicolumn{1}{|c|}{ Groundwater } & $\begin{array}{c}\text { Tritium Concentration } \\
(\mu \mathrm{Ci} / \mathrm{L})\end{array}$ & $\begin{array}{c}\text { Plume Surface Area } \\
\left(\mathrm{km}^{2}\right)\end{array}$ \\
\hline $\begin{array}{l}\text { 200-West Area } \\
\begin{array}{l}\text { SALDS projected to 2015 } \\
\text { north of 200-West Area) }\end{array}\end{array}$ & 0.02 to 0.6 & 4 \\
\hline 200 -East Area effluent & 0.02 to 3 & 0.1 \\
\hline $100-$ B, C Area & 0.02 to 3.2 & 195 \\
\hline $100-$ K Area & 0.020 to 0.027 & 0.03 \\
\hline $100-N$ Area & 0.020 to 0.51 & 0.08 \\
\hline $100-D$ Area & 0.020 to 0.057 & 1.3 \\
\hline $100-$ F Area & 0.020 to 0.030 & 0.3 \\
\hline 300 Area & 0.020 to 0.11 & 0.3 \\
\hline
\end{tabular}

\subsubsection{0-Area Tritium Plumes}

Tritium plumes with tritium concentrations greater than $20,000 \mathrm{pCi} / \mathrm{L}$ exist at the 100-BC, 100-K (two plumes), 100-N, 100-D, and 100-F Areas. The plume at 100-N Area extends to the Columbia River at concentrations greater than $20,000 \mathrm{pCi} / \mathrm{L}$. Outfalls from $100-\mathrm{N}$ Area to the river are also discharging tritium at concentrations greater than $20,000 \mathrm{pCi} / \mathrm{L}$.

\subsubsection{0-West Area Plumes}

Two plumes with tritium concentrations greater than 20,000 pCi/L exist within the 200-West Area with one of them extending east of the west area to near 200-East Area. A new SALDS site just north of the 200-West Area started to receive HTO at concentrations of about $5,000,000 \mathrm{pCi} / \mathrm{L}$ in December 1995 . The monitoring well reports for Fiscal Year (FY) 1996 did not indicate any concentrations greater than $20,000 \mathrm{pCi} / \mathrm{L}$ near this disposal site (Hartman 1997).

\subsubsection{0-East Area Plumes}

A sequential plume exists emanating from the 200-East Area and extending to the Columbia River. Tritium concentrations are shown as a function of time in Figure 10 to show the two migration periods. This plume extends to the river from the old Hanford townsite to near the 300 Area.

\subsubsection{Area}

One well in the 300 Area had an average yearly concentration value of $20,000 \mathrm{pCi} / \mathrm{L}$ for FY 1996. 


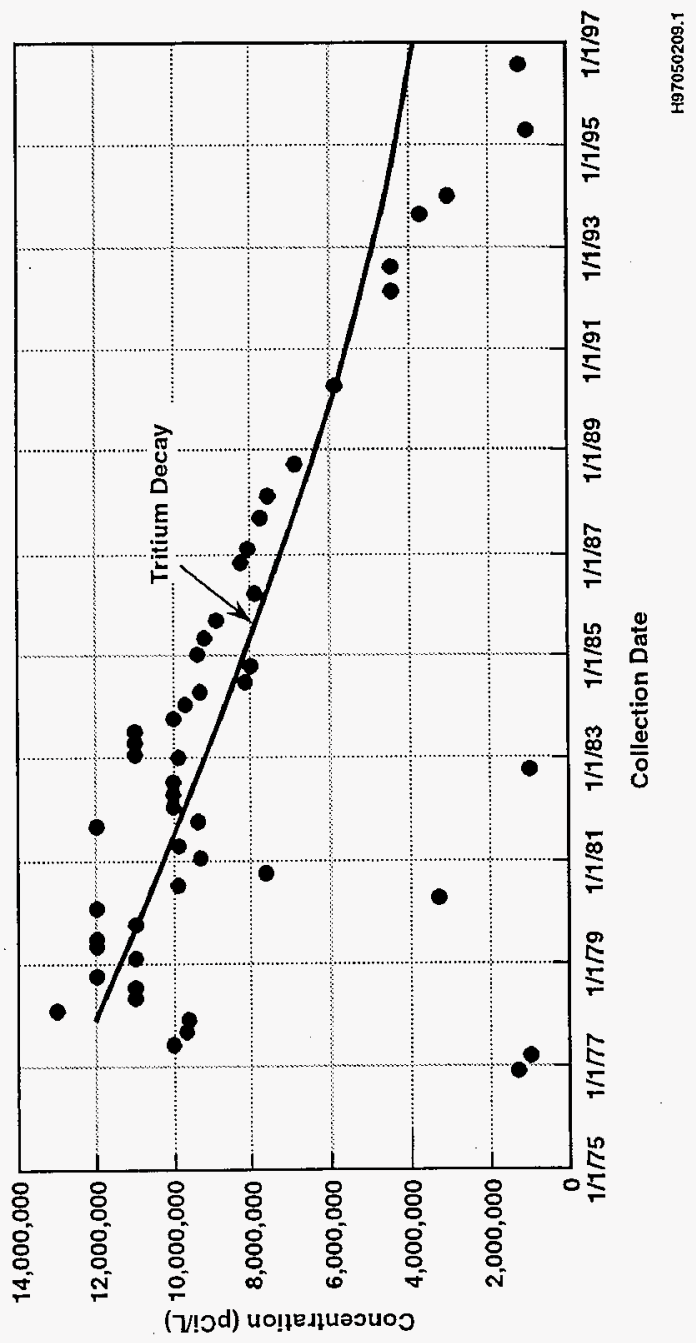

Figure 10. Tritium Concentration Trend in Well 299-0W22-9. 


\subsection{GROUNDWATER MODELING}

Groundwater modeling has been done and is being continued to closely approximate tritium (as well as other contaminants) concentrations measured in the Hanford Site aquifer from past discharges and to predict future behaviors. During the past several years, a three-dimensional flow and transport model has been under development by the Groundwater Surveillance Project to improve the simulation of groundwater flow and contaminant transport within the unconfined aquifer system. The model is based upon the Coupled Fluid Energy, and Soluble Transport (CFEST) code (Gupta et. a]. 1987). The mode i includes nine layers above the top of the basalt to represent the major hydrogeologic units within the unconfined aquifer system.

A separate Bechtel Hanford, Inc. (BHI) modeling effort was completed in FY 1996 with the objective of prioritizing and optimizing environmental restoration activities. This modeling simulated the migration of eight radionuclides (including tritium) and chemical contaminant plumes over the next 200 years. This simulation consisted of a two-layer model based upon the Variable Saturated Analysis Model in 3 Dimensions with Preconditioned Conjugate Gradient Matrix Solvers (VAM3DCG) code (developed by HydroGeoLogic, Inc. Herndon, Virginia).

\subsection{OPERATION OF STATE-APPROVED LAND DISPOSAL SITE}

The SALOS located just north of the 200-West Area began receiving tritiated wastewaters in December 1995. It is designed for a 30-year operating period and has a specified amount of tritium to be received as $3,300 \mathrm{C} i$ over $i$ ts lifetime. It currently receives condensate from the ETF which is free of all contaminants except tritium. The tritium comes from processing wastes from single-shell and double-shell tanks and other miscellaneous wastes on the Hanford Site. Basin waters from KE, KW, and $\mathrm{N}$-Reactor basins are expected to be processed through ETF with their tritium contents being discharged to this location.

SALDS is the prescribed location because it is determined by groundwater sample results evaluation and groundwater flow modeling to allow sufficient decay of the tritium prior to discharge to the Columbia River. A minimum 80 -year decay time is expected prior to migration to the river. Further evaluations are being conducted to firm up these conclusions.

Tritium releases to the SALDS amounted to $228 \mathrm{Ci}$ from December 1, 1995, to December 31,1996 , in $14,840,000 \mathrm{~L}$. This amounts to an average tritium concentration of about $8.0 \mu \mathrm{Ci} / \mathrm{L}$ and $56 \mathrm{~L} / \mathrm{min}$ flow.

\subsection{COLUMBIA RIVER}

Tritium enters the Columbia River by groundwater seepage as it passes through the Hanford Site at several locations along the shoreline and through outfalls in the 100 Area. The quantity of tritium entering the river as it passes through the Hanford Site is estimated to be less than 4,500 Ci in Calendar Year 1995. This estimate was based upon the difference in concentration from Priest Rapids location to the City of Richland water intake location. Monthly composites of weekly samples were obtained at both locations. The 1995 mean tritium concentration at Priest Rapids was $34.4 \mathrm{pCi} / \mathrm{L}$, and at the Richland pumphouse, it was $79.0 \mathrm{pCi} / \mathrm{L}$ (Bisping 1996). 
It should be noted that river samples taken from other locations along the Hanford Site and analyzed contained up to about $180 \mathrm{pCi} / \mathrm{L}$. These values are well below the MCL of $20,000 \mathrm{pCi} / \mathrm{L}$ for tritium. The mean tritium concentration value at the Richland pumphouse is reported to be higher than the river cross-sectional average for high-water flow at this location because the tritium is thought to be unevenly mixed in the river at this location.

Sampling along a river cross section at the Richland pumphouse during 1995 confirmed the existence of a concentration gradient during high-river flowrates (Saldi 1996). This greater value is thought to be attributed to the tritiated groundwater from the 200 Area groundwater plume entering the river along the portion of shoreline extending from the old Hanford townsite to the 300 Area which happens to be on the same side of the river as the Richland pumphouse intake. With a mean Columbia River flowrate past the Hanford Site of $1.01 \mathrm{E}+14 \mathrm{~L} / \mathrm{yr}$ (Bisping 1996), this amounts to less than 4,500 Ci tritium/yr entering the river from the Hanford Site. Most of this tritium appears to be entering the river near the old Hanford townsite.

The Hanford Site upstream and downstream tritium concentrations of the Columbia River are above the natural background tritium concentration (pre-1954 tritium concentrations of about $3.1 \mathrm{pCi} / \mathrm{L}$ ). The bulk of the $34.4 \mathrm{pCi} / \mathrm{L}$ in the river upstream of the Hanford Site comes from fallout from nuclear bomb testing in the 1950 s through $1970 \mathrm{~s}$. The peak concentration in the Columbia River upstream of the Hanford Site was $280 \mathrm{pCi} / \mathrm{L}$ in 1980 . The peak downstream concentration was $320 \mathrm{pCi} / \mathrm{L}$ in 1980.

\subsection{TRITIUM STORED IN SOLID-WASTE DISPOSAL SITES}

About $800,000 \mathrm{Ci}$ of tritium have been stored as solid waste in trenches in the 200-East and 200-West Areas. Since 1993, tritium has been received from Princeton in high-integrity containers for disposal in trenches at the Hanford Site. This tritium is loaded on molecular sieve material and packaged inside polyethylene enduro packs with welded closures. This material is packaged to contain the tritium for hundreds of years and the tritium is not expected to leak from the container in a liquid form.

Much of the tritium dispositioned to the 200-West Area trenches as solid waste was dispositioned prior to 1976 . The integrity of these containers ........TBD

Well monitoring of these trenches have not indicated any leakage to date.

\subsection{REFERENCES}

Allen, W. L., 1995, Tritiated Wastewater Treatment and Disposal Evaluation for 1995, DOE/RL-95-68, U.S. Department of Energy, Richland Operations, Richland Washington.

Arita, T., T. Yamanishi, Y. Iwai, 1996, "A Tritium Recovery System from Waste Water of Fusion Reactor Using CECE and Cryogenic-Wal7 Thermal Diffusion Column," Fusion Technology Vol. 30, December 1996. 
Barnett, D. B., J. S. Schmid, S. S. Lowe, W. L. Allen, N. A. Ballantyne, "C. H. Hanford Site Ground Water Protection Plan," 1995, DOE/RL-89-12, Rev. 2, U.S. Department of Energy, Richland Operations Office, Richland, Washington.

Bartoszek, F. E., 1988, et a1. "Progress in Laser-based Tritium Separation," Fusion Technology, Volume 14.

Busigin, A., S. K. Sood, "Flowsheet - A Computer Program for Simulating Hydrogen Isotope Separation Systems," Fusion Technology, Volume 14, September 1988 .

Chamness, B. S., and J. K. Merz, 1997.

Dresel, P. E., J. T. Rieger, W. D. Webber, P. D. Thorne, B. M. Gillespie, S. P. Luttre11, S. K. Wurstner, and T. L. Liikala, 1996, "Hanford Site Ground-Water Monitoring for 1995," PNNL-11141, Pacific Northwest Laboratory, Richland, Washington.

Evans, D. K., "Laser Applications in Physical Chemistry," Marcel Dekker, New York, 1989.

Fulbright, H. H., et a7., "Status and Practicality of Detritiation and Tritium Reduction Strategies for Environmental Remediation," WHC-RP-96-0075, Rev. 0, Westinghouse Savannah River Company, Aiken, South Carolina 29808.

Gates, D. D., "Evaluation of Ground Freezing for Environmental Restoration at Waste Area Grouping 5," Oak Ridge National Laboratory, Oak Ridge Tennessee, ORNL/ER-337, Lockheed Martin Energy Systems, Inc., September 1995.

Gupta, S. K., C. R. Cole, C. T. Kincaid, and A. M. Monti, 1987, "Coupled, Fluid Energy, and Solute Transport (CFEST) Model: Formulation and User's Manual," BMI/ONWI-660, Battelle Memorial Institute, Columbus, Ohio.

Hartman, M. J., 1997, et. a1. "Hanford Site Groundwater Monitoring for Fiscal Year 1996," PNNL-11470, Pacific Northwest National. Laboratory, Richland, Washington.

Hendrickson, D. W., 1995, Grout treatment Facility Waste Feed Projections, WHC-SD-WM-TI-528, Westinghouse Hanford Company, Richland, Washington, June 1995.

Horen, A. S. and M. W. Lee, "Metal Hydride Based Isotope Separation Large-Scale Operation," Fusion Technology, Volume 21, March 1992.

Isomura, S., K. Suzuke, M. Shibuya, "Separation and Recovery of Tritium BY Hydrogen-Water Isotopic Exchange Reaction, "Fusion Technology, Volume 14, September 1988.

Jeppson, D. W., 1973, "Tritium Effluents During Zirconium Alloy-Clad Fuel Processing, Tritium Control Technology," WASH-1269, Mound Laboratory, December 1972

Kalyanam, K. M. and S. K. Sood, "A Comparison of Process Characteristics for the Recovery of Tritium from Heavy Water and Light Water Systems, "Fusion Technology, Volume 14, September 1988. 
Katz, J. J., "Deuterium and Tritium, Kirk-0thmer Encyclopedia of Chemical Technology, " $4^{\text {th }}$ Edition, Volume 8, 1993, John Wiley and Sons, Inc.

Kei1, W., E. Erdle, 1988, "Tritium-Enrichment VIA CECE-Process with High Temperature Steam Electrolysis (HOT ELLY), "Fusion Technology, Volume 14, September 1988.

King, C. M., V. Van Brunt, R. B. King, and A. R. Gart, 1991, "Concepts for Detritiation of Waste Liquids, "WSRC-MS--91-027, Waste Management 1991, Tucscon, Arizona.

Kveton, 0. K., H. Yoshida, J. E. Koonce, R. Haange, H. Horikiri, S. K. Sood, C. Fong, K. M. Kalyanam, and A. Busigin, "Design of the Water Detritiation and Isotope Separation Systems for ITER, "Fusion Technology, Volume 28, October 1995.

McConachie, W. A., Lawrence Livermore National Laboratory, Letter to Feather, R. L. Tan, S. Timm, California Environmental Protection Agency, dated February 13, 1996 with attached report, "Tritium Geochemistry and Ground Water Treatment Technology for the Building 850/Pit 7 Complex Operable Unit, Lawrence Livermore Laboratory (LLNL) Site 300."

Motyka, T., "Replacement Tritium Facility," Fusion Technology, Volume 21, March 1992.

Nelson, D. A., J. B. Duncan, G. A. Jensen, and S. D. Burton, 1996, "Isotopomeric Water Separations With Supported Polyphosphazene Membranes," Journal of Membrane Science, 112 (1996) 105-113.

Nelson, D. A., J. B. Duncan, G. A. Jensen, and S. D. Burton, 1994", "Membrane Mediated Separation of Tritiated Water from Water Without Phase Change," Proceedings American Nuclear Society, Volume 71, page 82, November 1994.

Nelson, D. A., J. B. Duncan, G. A. Jensen, and S. D. Burton, $1994^{\mathrm{b}}$, "Separation of HTO From Water Using Membrane Technology," Proceedings of the 15th Annual Conference, Canadian Nuclear Society, June 1994.

Rae, H. K., "Separation of Hydrogen Isotopes," American Chemical Society, 1978.

Roblyer, S. P., 1994, "Plutonium and Tritium Produced in the Hanford Site Production Reactors," WHC-SD-CP-RPT-014, Westinghouse Hanford Company, Richland Washington.

Saldi, K. A. and R. L. Dirkes, 1996, "Surface Water and Sediment Surveillance Hanford Site Environmental Report for CY 1995, "PNNL-11139, Pacific Northwest National Laboratories, Richland, Washington.

Schwirian-Spann, A. L., V. Van Brunt, and C. M. King, 1994, "CataTyzed Absorption/Stripping of Aqueous Detritiation, "American Institute of Chemical Engineers, Annual Meeting, November 1994, San Francisco, Cal ifornia.

Sienkiewicz, C. J. and J. E. Lentz, "Recovery of Tritium from Water, "Fusion Technology, Volume 14, September 1988, Elsevier, Amsterdam, Holland. 
Simpson, B. C., 1994", "Tank Characterization Report for Double She1) Tank 241 AP 101,"WHC-WM-ER-357-Rev 0, Westinghouse Hanford Company, Richland, Washington, September 1994.

Simpson, B. C., 1994" "Tank Characterization Report for Double She11 Tank 241 AP 102," WHC-WM-ER-358-ReV 0, Westinghouse Hanford Company, Richland, Washington, September 1994.

Simpson, B. C., 1994" "Tank Characterization Report for Double Shel1 Tank 241 AP 103," WHC-WM-ER-359-Rev 0, Westinghouse Hanford Company, Richland, Washington, September 1994.

Simpson, B. C., 1994" "Tank Characterization Report for Double She11 Tank 24l AP 105," WHC-WM-ER-360-Rev 0, West inghouse Hanford Company, Richland, Washington, September 1994.

Simpson, B. C., 1994", "Tank Characterization Report for Double She 17 Tank 24l AP 106," WHC-WM-ER-361-Rev 0, Westinghouse Hanford Company, Richland, Washington, September 1994.

Simpson, B. C., 1994 ${ }^{\mathrm{f}}$, "Tank Characterization Report for Double Shell Tank 24l AP 107," WHC-WM-ER-362-Rev 0, Westinghouse Hanford Company, Richland, Washington, September 1994.

Simpson, B. C., 1994" "Tank Characterization Report for Double She11 Tank 241 AW 105," WHC-WM-ER-354-Rev 0, Westinghouse Hanford Company, Richland, Washington, September 1994.

Sood, S. K. and K. M. Kalyanam, "Tritiated Water Processing for Fusion Reactors, Transactions of Fusion Technology, "Volume 27, March 1995.

Spagnolo, D. A., A. E. Everatt, P. W. K. Set, and K. T. Chuang, "Enrichment and Volume Reduction of Tritiated Water," Fusion Technology, Volume 14, September 1988.

State of Washington Department of Ecology (Ecology), 1995 State Waste Discharge Permit (216 Permit) for the 200 Area ETF, Permit No. ST 4500 , issued in compliance with the provisions of Chapter $90.48 \mathrm{RCW}$, as amended, and Chapter 173-2I6 WAC, as amended, 07ympia, Washington.

Takeuchi, K. et a1., "Three-Compartment Photoreactor for Laser Isotope Separation of Tritium, "Separation Science and Technology, 22(1), pp. 95-102, 1987.

Takeuchi, K., Personnel communication with R. K. Biyani, March 1997.

U.S. Patent No. 5,451,322, "Method and Apparatus for Tritiated Water Separation," September 19, 1995, David A. Nelson, James B. Duncan, and George A. Jensen.

Van Hook, W. A., 1968, "Vapor Pressures of the Isotopic Waters and Ices, "The Journal of Physical Chemistry, Volume 72, Number 4, Apri1 1968.

Vasaru, Gheorge, "Tritium Isotope Separation," CRC Press, Boca Raton, 1993. 
Villigas, A. and A. Smith, 1995, "A System Engineering Analys is to Examine the Economic Impact for Treatment of Tritiated Water in the Hanford KE-Basin," Waste Management, 1995, Tucson, Arizona.

Yamai, H., S. Konishi, M. Hara, K. Okuno, I. Yamamoto, "Tritiated Water Processing Using Liquid Phase Catalytic Exchange and Solid oxide Electrolyte Cel1," Fusion Technology, Volume 28, October 1995.

Woodal1, Ken, Personnel Communication with D. W. Jeppson, February 15, 1997.

Wurstner, S. K., P. D. Thorne, M. A. Chamness, M. D. Freshley, M. D. Williams, 1995, "Development of three Dimensional Ground Water Modeling of Hanford Site Aquifers System: FY 1995 Status Report," PNL-10886, Pacific Northwest Laboratory, Richland, Washington 